\title{
Bank liquidity creation following regulatory interventions and capital support
}

\author{
Allen N. Berger ${ }^{1}$ \\ University of South Carolina, Wharton Financial Institutions Center, and European Banking Center \\ Christa H. S. Bouwman ${ }^{2}$ \\ Texas A\&M University and Wharton Financial Institutions Center \\ Thomas Kick ${ }^{3}$ \\ Deutsche Bundesbank and University of Nuremberg \\ Klaus Schaeck $^{4 *}$ \\ Lancaster University \\ January 2016
}

We study the effects of regulatory interventions and capital support (bailouts) on banks' liquidity creation. We rely on instrumental variables to deal with possible endogeneity concerns. Our key findings, which are based on a unique supervisory German dataset, are that regulatory interventions robustly trigger decreases in liquidity creation, while capital support does not affect liquidity creation. Additional results include the effects of these actions on different components of liquidity creation, lending, and risk taking. Our findings provide new and important insights into the debates about the design of regulatory interventions and bailouts.

Keywords: liquidity creation, bank distress, regulatory interventions, capital support, bank bailouts JEL Classification: G21, G28

1 Moore School of Business, University of South Carolina, 1014 Greene Street, Columbia, SC 29208, United States. E-mail: aberger@moore.sc.edu

2 Mays Business School, Texas A\&M University, 4218 TAMU, College Station, TX 77845, United States. E-mail: cbouwman@tamu.edu

3 Deutsche Bundesbank, Wilhelm-Epstein-Str. 14, 60431 Frankfurt am Main, Germany. E-mail: thomas.kick@bundesbank.de

4 Lancaster University Management School, Lancaster University, Bailrigg, LA14YX Lancaster, United Kingdom. Email: k.schaeck@lancaster.ac.uk

* Corresponding author.

A previous version of this paper was entitled "Bank risk taking and liquidity creation following regulatory interventions and capital support." We thank the Editor, Murillo Campello, an anonymous Associate Editor, and an anonymous referee for comments and suggestions that significantly helped improve and polish this paper. We are also grateful to Yener Altunbas, Christina Bannier, Charles Calomiris, Hans Degryse, Bob DeYoung, Klaus Düllmann, Mariassunta Giannetti, Martin Goetz, Owain ap Gwilym, Philipp Hartmann, Chris James, Alexey Levkov, Thilo Liebig, Gyongyi Loranth, Angela Maddaloni, Phil Molyneux, Leonard Nakamura, Lars Norden, Enrico Onali, Steven Ongena, Raluca Roman, Sascha Steffen, Claus Schmitt, Greg Udell, Wolf Wagner, and Tanju Yorulmazer for useful suggestions. Seminar and conference participants at the Deutsche Bundesbank Seminar on Banking and Finance; Bangor Business School; European Central Bank; Miami University; Indiana University; Case Western Reserve University; Royal Economic Society Conference; RTF Workshop on Challenges for Regulators in the New Financial Landscape; European Economic Association Meeting; European Finance Association Meeting; Conference on Information, Liquidity and Trust in Incomplete Financial Markets; Conference on Liquidity and Liquidity Risks; Financial Management Association Meeting; Financial Intermediation Research Society Meeting; Financial Stability Conference; FDIC/JFSR Annual Bank Research Conference; Macro and Financial Econometrics Conference; Symposium on Banking, Finance, and Insurance; and the Banque de France/Toulouse School of Economics also had many useful comments and suggestions. Klaus Schaeck was visiting the Deutsche Bundesbank when this project was initiated. He acknowledges support from the Leverhulme Trust (Grant F/00174/Q) and the hospitality of the Deutsche Bundesbank. This paper represents the authors' personal opinions and does not necessarily reflect the views of the Deutsche Bundesbank or its staff. 
Debates about the optimal design of bank safety nets and the consequences of regulatory interventions into and bailouts of distressed banks feature prominently in recent years. When banks are troubled, authorities often take actions aimed at reducing bank risk taking to limit failures, minimize losses to the deposit insurer and taxpayers, and avoid disruptions to the economy. ${ }^{1}$ These actions typically involve regulatory interventions (intrusions by regulators such as instructions to: dismiss executives, pay fines, change processes, or restrict some activities), and/or bailouts in the form of capital support. A growing literature examines how such actions affect bank performance with a particular focus on risk taking (e.g., Dam and Koetter, 2012; Delis, Tsoumas, and Staikouras, 2013).

However, little is known about how these actions affect banks' ability to create liquidity for their customers, a core function of banks which supports the macroeconomy. ${ }^{2}$ We know of no empirical work on the effects of regulatory interventions on liquidity creation, and only a few studies on the effects of capital support on one element of liquidity creation, lending. ${ }^{3}$ There is, however, related theory on these issues. One theory predicts that regulatory interventions trigger reductions in portfolio risk (Mailath and Mester, 1994), and since the portfolio adjustments may involve reductions in risky lending activities, bank liquidity creation may decline as well. The theories on the role of capital, which is increased by capital support, yield conflicting predictions about how capital affects liquidity creation as we explain in detail in Section 3.2. ${ }^{4}$ Interestingly, authorities often state higher lending (a key component of bank liquidity creation) as an explicit

\footnotetext{
${ }^{1}$ James (1991) shows that bank failures can cause large losses to the deposit insurer, and Samolyk (1994) documents that bank failures are a prime factor for transmission of shocks from the banking sector to the real economy.

${ }^{2}$ Banks create liquidity on the balance sheet by transforming illiquid assets such as loans into liquid liabilities such as transactions deposits; they also create liquidity off the balance sheet through loan commitments and similar claims to liquid funds (see Berger and Bouwman, 2009; Donaldson, Piacentino, and Thakor, 2015 for summaries).

${ }^{3}$ In related literature, there are studies on the effects of changes in capital requirements on lending, a key component of liquidity creation (e.g., Berger and Udell, 1994; Peek and Rosengren, 1995; Thakor, 1996), as well as studies of changes in supervisory toughness on lending (e.g., Bizer, 1993; Berger, Kyle, and Scalise, 2001; Kiser, Prager, and Scott, 2012).

${ }^{4}$ Capital support and higher capital also often enhance the bank's probability of survival, particularly during financial crises (Kick, Koetter, and Poghosyan, 2010; Berger and Bouwman, 2013).
} 
goal of capital support (e.g., Philippon and Schnabl, 2013; Duchin and Sosyura, 2014).

Empirical investigation of these topics is challenging for four reasons. First, information about regulatory interventions and capital support is usually confidential. We overcome this challenge by exploiting unique supervisory data from the Deutsche Bundesbank (henceforth Bundesbank) that include information on all actions taken by authorities in Germany from 19992009. The authorities include government agencies (which engage in regulatory interventions and some capital support) and bankers associations' insurance schemes (which provide most of the capital support).

A second challenge is that even when authorities' actions are made public, such actions are typically only observed during crises, potentially confounding the effects of the actions with those of the crisis. An advantage of our sample is that it spans crisis as well as non-crisis years, and regulatory interventions and capital support occur frequently during both time periods.

A third challenge is that researchers typically have information only on subsets of the actions by authorities (e.g., they may have data on capital support but not on regulatory interventions). They may thus inadvertently ascribe the effects of the missing actions to the observed actions. We do not face this challenge as we have data on all such actions in Germany.

A final challenge is an identification problem that arises from the non-randomness of these actions. Naïvely regressing changes in liquidity creation on regulatory interventions and capital support may fail to identify causal effects. Even in the absence of these actions, banks may recognize problems and adjust liquidity creation. For example, being troubled may diminish banks' ability to offer long-term loans and loan commitments, reducing liquidity creation, while at the same time also triggering actions by authorities. We deal with this issue using instrumental variable (IV) analysis, employing three instruments for regulatory interventions and capital support.

The first instrument is the vote share of political parties with pro-business orientation in 
federal state elections, where timing follows an exogenously imposed rule. This instrument reflects a crucial feature of the German institutional framework in which politicians appoint regulators. As shown in Dam and Koetter (2012) and described in detail below, this instrument allows us to isolate plausibly exogenous variation in interventions arising from the political situation on the federal state level. Moreover, this approach is also in line with a growing literature which stresses the role of political connections in government interventions and capital support in banking (Brown and Dinc, 2005; Bayazitova and Shivdasani, 2012; Dam and Koetter, 2012; Duchin and Sosyura, 2012, 2014).

The second instrument is the distance between a bank's headquarters and the location of the corresponding bankers associations' insurance scheme which may provide capital support. Distance proxies for information asymmetries and transportation costs (Degryse and Ongena, 2005) which impede the insurance scheme's ability to monitor a bank's condition. This may reduce the likelihood of capital support, but may increase the likelihood of interventions by regulators to compensate.

The third instrument, the availability of a possible acquirer, exploits unique legal provisions in Germany which restrict the availability of possible acquirers for ailing banks. This instrument builds on the insight that acquisitions may substitute for regulatory interventions and capital support because private-sector arrangements are the preferred way of resolving bank distress in Germany.

As part of our empirical tests below, we document that all our instruments are strong and satisfy the overidentification restrictions. We also present economic arguments to illustrate that our instruments are plausibly exogenous. Since the instruments are most appropriate for banks that operate in geographically delimited markets, our main analyses focus on banks that operate in local markets, but the results also hold when banks that operate nationwide are included.

Our key dependent variable, bank liquidity creation, is calculated using a slight variation of Berger and Bouwman's (2009) methodology, described in detail in Appendix A. In brief, liquidity 
creation is the weighted sum of all asset-side, liability-side, and off-balance sheet activities. Since liquidity is created when banks transform illiquid assets (e.g., long-term loans) into liquid liabilities (e.g., transactions deposits), we give positive weights to both illiquid assets and liquid liabilities. Similarly, since banks destroy liquidity when they transform liquid assets (e.g., securities) into illiquid liabilities (like subordinated debt), we give negative weights to liquid assets and illiquid liabilities. Off-balance sheet activities (e.g., loan commitments) receive weights consistent with those assigned to functionally similar on-balance sheet activities. We analyze total liquidity creation for each bank, and also its components (asset-side, liability-side, and off-balance sheet liquidity creation). Further tests investigate lending (one key component of asset-side liquidity creation) and risk taking.

Over our sample period of 1999 - 2009, regulators intervened into 278 banks (11\% of banks) and capital support was provided to 114 banks (5\%). Capital support averaged 36\% of Tier 1 capital. A total of 33 banks (1\%) were subject to both actions. Thus, sizeable proportions of banks received regulatory interventions and/or capital support, allowing for meaningful analyses.

Our key findings are that regulatory interventions robustly decrease liquidity creation, while capital support does not affect liquidity creation. We run many additional tests. For example, to address whether unhealthy banks react more intensively to regulatory interventions and capital support, we split the sample at the median equity ratio. These tests yield intuitive results. Regulatory interventions display significance for banks with capital ratios below the median, and the effect is greater in magnitude than for the full sample. We find no significant effects on banks with equity ratios above the median. The effects of capital support remain insignificant across these subsamples.

To better understand the driving forces behind the declines in liquidity creation, we decompose liquidity creation into asset-side, liability-side, and off-balance sheet liquidity creation. 
We show that regulatory interventions reduce liquidity creation on the liability side and off the balance sheet, but do not affect liquidity creation on the asset side. Capital support reduces assetside liquidity creation but increases liability-side liquidity creation: these two effects cancel out each other, explaining why we find no overall effect of capital support on the bank's total liquidity creation.

We also examine asset-side liquidity creation from a different perspective by looking at lending. We find that capital support reduces total loans, in line with our finding that capital support reduces asset-side liquidity creation, and this effect is larger for corporate loans than for retail loans.

We further check whether regulatory interventions and capital support have the intended effect of reducing risk taking. We find that risk taking declines in response to both actions.

One might expect that authorities' actions do not have as much bite when the threat is perceived to be less. To address this, we decompose regulatory interventions alternatively into moderate versus severe ones, and into ones that target business activities versus management. We find our results to be generally weaker when regulatory interventions are moderate and when they target business activities.

Our findings provide insights into the design of prudential regulation and supervision of banks. First, they suggest that regulatory interventions trigger possibly unintended consequences in that they reduce liquidity creation, with potentially adverse consequences for the macroeconomy. Beyond considering the effects on risk taking, regulatory authorities might also consider the impact on the macroeconomy when deciding on interventions. Second, our results suggest that capital support does not affect the ability to create liquidity. This contributes to the literature on capital support, which finds conflicting results (Gropp, Hakenes, and Schnabel, 2011; Black and Hazelwood, 2013; Giannetti and Simonov, 2013; Li, 2013, Duchin and Sosyura, 2014; Berger and Roman, 2015). 
Our paper is also related to several other strands of literature. It builds on studies on the effect of regulations on bank soundness (Barth, Caprio, and Levine, 2004; Demirgüç-Kunt, Detragiache, and Tressel, 2008; Delis and Staikouras, 2011). It informs the debate on optimal closure and bailout policies (Boot and Thakor, 1993; Mailath and Mester, 1994; Aghion, Bolton, and Fries, 1999; Dwyer and Hasan, 2007; Ennis and Keister, 2010; Bhattacharya and Nyborg, 2013). Our findings also complement Delis, Tsoumas, and Staikouras (2013), who show that regulatory enforcement actions issued in response to safety and soundness concerns in the U.S. do not consistently reduce bank risk taking, while supervisory actions aimed at internal control and risk management help improve bank soundness. Our work extends research on safety net features in Germany by Dam and Koetter (2012), Fischer, Heinz, Rocholl, and Steffen (2012), and Gropp, Gruendl, and Guettler (2014). None of these studies provide direct evidence on the effects of authorities' actions on bank liquidity creation.

We proceed as follows. Section 1 discusses the institutional background. Section 2 describes our identification strategy and Section 3 contains the results. Section 4 concludes.

\section{Institutional Background}

\subsection{German banking sector}

The German banking sector has three pillars: private-sector, public-sector, and cooperative banks, which differ in ownership structures and geographical reach (Brunner, Decressin, Hardy, and Kudela, 2004). The private-sector pillar contains nationwide and foreign banks, as well as small banks operating in local markets. Public-sector banks include savings banks and Landesbanks owned by governments at the city-, county-, or state-level. The cooperative pillar comprises cooperative banks and central credit cooperatives. Savings banks and cooperative banks operate in geographically segmented markets, reflecting a regional principle ("Regionalprinzip”), which 
constrains these banks' activities to their assigned regions. ${ }^{5}$ A region usually consists of one or a limited number of multiple (contiguous) counties. The regional principle is embedded in statute for savings banks, and also de facto enforced for cooperative banks.

The German regulatory framework shares similarities with other European countries, Japan, and the U.S., and the regulatory interventions and capital support used in Germany have also been employed in those countries (e.g., Houston and James, 1993; Bayazitova and Shivdasani, 2012; Black and Hazelwood, 2013; Delis, Tsoumas, and Staikouras, 2013; Giannetti and Simonov, 2013; Li, 2013; Duchin and Sosyura, 2014; Berger and Roman, 2015). There are, however, differences in the institutional design of safety net arrangements and the implementation of rescue packages.

\subsection{Regulatory interventions and capital support}

The Federal Financial Supervisory Authority ("Bundesanstalt für Finanzdienstleistungsaufsicht," BaFin) is responsible for regulatory interventions. However, the BaFin collaborates closely with the Bundesbank in this process. In most instances, the Bundesbank collects the data on violations of the Banking Act and recommends that the BaFin take action. The BaFin may then decide to take action after additional consultation with the Bundesbank, particularly with the supervisor from the regional Bundesbank office responsible for on-site supervision of the bank. The regional Bundesbank office is located either in the federal state capital or, in instances where the regional Bundesbank office is responsible for multiple federal states, in the largest metropolitan area in these states.

We classify all actions mentioned in the German Banking Act (Articles 45-48) as regulatory interventions: restrictions and prohibitions of deposit taking, restrictions and prohibitions of lending activities, restrictions and prohibitions of profit distribution, restructuring of business activities (primarily of lending activities), limitations on the scope of managerial decisions, instructions to the

\footnotetext{
${ }^{5}$ Appendix B shows the geographic segmentation of banking markets in Germany. It uses the federal state Bavaria as an example ("Bundesland", Figure B.1) and illustrates its administrative district borders ("Regierungsbezirke", Figure B.2) and county borders in Upper Bavaria ("Landkreise", Figure B.3). Counties are nested within administrative districts.
} 
bank's management, ${ }^{6}$ appointment of a trustee, actual dismissal of executives, hearings about dismissal of executives, official disapprovals, fines for executives, fines for the institution, warnings of executives, and threats of measures according to the Banking Act. We focus on these interventions because they are moderate to severe intrusions which may affect liquidity creation. ${ }^{7}$ Routine letters are the only actions we do not classify as regulatory interventions, since these are minor and less likely to affect bank behavior. Untabulated regressions confirm that liquidity creation does not change significantly after routine letters are sent.

Capital support is primarily provided by the bankers associations' insurance schemes. Each of the three banking pillars has one umbrella bankers association, and several regional subassociations, typically at the state level. Member institutions receive compulsory insurance from their umbrella organization (banks in the private-sector and cooperative pillars) or from their regional sub-association (banks in the public-sector pillar). Similar to the FDIC in the U.S., insurance schemes engage in on- and off-site monitoring. These monitoring activities are independent of the surveillance activities of the BaFin and the Bundesbank. All insurance schemes are risk-based, funded by banks, and are not guaranteed by taxpayers.

Capital support by an insurance scheme requires approval by its board (appointed by representatives of member banks, e.g., executive officers and nonexecutives of member banks) or a committee of the insurance scheme. It targets the weakest institutions, is involuntary, and in some cases is tied to liquidating reserves or signing debtor warrants. ${ }^{8}$ The government provided capital support to six troubled banks in our sample during the recent crisis via the Financial Market

\footnotetext{
${ }^{6}$ These instructions are not officially defined but are applicable if the institution is "in danger to the discharge of an institution's obligations to its creditors, especially to the safety of the assets entrusted to it, or if there are grounds for suspecting that effective supervision of the institution is not possible" (Article 46, Section 1, No. 1).

${ }^{7}$ The effects of regulatory interventions on liquidity creation are ambiguous due to the way liquidity creation is measured. For example, one might expect that lending restrictions reduce liquidity creation but this is not necessarily true since different loan categories enter the calculation of liquidity creation with positive, negative, or zero weights.

${ }^{8}$ Once a bankers associations' insurance scheme classifies a bank as insolvent, and if there is no other bank available to acquire the distressed entity, the bank in question receives capital support to meet regulatory requirements.
} 
Stabilization Fund ("Bundesanstalt für Finanzmarktstabilisierung," SoFFin). Our tests combine capital support by the bankers associations' insurance schemes and the SoFFin, but the results are robust to excluding the SoFFin-supported banks. The results are available upon request.

There is no predetermined ordering of the timing of regulatory interventions and capital support. Banks may receive regulatory interventions before capital support ( $18 \%$ of all cases), in the year of capital support (7\%), after capital support (10\%), or without receiving capital support at any point (65\%). Appendix C presents additional details. Figures C.1 and C.2 show the geographic distribution of regulatory interventions and capital support, respectively. Figure C.3 reports the average Z-Score of the sound banks. All maps in Appendix C report quintiles. Two observations are noteworthy: First, soundness varies in several instances with state borders, highlighting that the inclusion of state fixed effects is useful for our empirical tests. Second, in areas with banks that have many regulatory interventions or capital support, the other banks tend to operate with relatively high Z-Scores, suggesting that observing distress among nearby banks may trigger changes in behavior by competitors, an issue that suggests scope for future research.

\section{Identification strategy and data}

\subsection{Instrumental variable (IV) regressions}

To examine the effect of regulatory interventions and capital support on liquidity creation, we use the following regression setup:

$$
\begin{aligned}
& \Delta Y_{i, t}=\beta_{1}+\beta_{2} \text { RegulatoryInterventions }_{i, t-1}+\beta_{3} \text { CapitalSupport }_{i, t-1}+\text { B }_{4}^{\prime} \text { Controls }_{i, t-1} \\
& \quad+\gamma \text { BankingPillar }_{p}+\delta \text { Year }_{t}+\text { EState }_{s}+\epsilon_{i, t}
\end{aligned}
$$

where $\Delta Y_{i, t}$ is the change in liquidity creation (or one of its components: asset-side, liability-side, and off- balance sheet liquidity creation) scaled by total assets at bank $i$ from year $t$-1 to year $t$, and $t-1$ is the year in which regulatory interventions or capital support took place. Regulatory interventions and capital support are defined in Section 2.2. The coefficients of interest are $\beta_{2}$ 
and $\beta_{3}$. Section 2.4 discusses the control variables and explains why we include banking pillar, year, and state dummies. Standard errors are clustered at the bank level to control for serial correlation within each bank.

Clearly, unobserved differences across banks that do not vary over time may result in bank heterogeneity that ultimately drives our inferences for the effects of regulatory interventions and capital support. To remove these time-invariant bank-specific effects, we follow the approach suggested in Wooldridge (2002), which is also widely used in corporate finance and banking (e.g., MacKay, 2003; Hennessy and Whited, 2007; Wintoki, Linck, and Netter, 2012; Ellul and Yerramilli, 2013; Bonaccorsi di Patti and Sette, forthcoming), and estimate all regressions in first differences, i.e., in changes from one period to the next period. Importantly, while first differencing is similar to the inclusion of bank fixed effects in that both remove time-invariant bank-specific unobservables, Ellul and Yerramilli (2013) highlight a key advantage of first differences: they focus on deviations of variables from their values in the previous period. This is important since bank fixed effects estimation is based on deviations from the mean for the bank and may introduce lookahead bias since means are calculated over the entire sample period. ${ }^{9}$ Similar to Nini, Smith, and Sufi (2012), we keep financial condition variables in levels to control more flexibly for the evolution of bank soundness over time. Regulatory interventions and capital support are also in levels as we view them as shocks. All other dummies enter in levels as well, as does the distance to the nearest metropolitan area.

Estimating the regression equations also gives rise to identification challenges. Distressed banks may be aware of their unsound operations and may adjust their liquidity creation independent of actions by authorities. Further, regulatory interventions and capital support are not assigned

\footnotetext{
${ }^{9}$ Note that our tests not only include year fixed effects to net out any variation that affects all banks across Germany equally in a given year but also include state fixed effects to control for macroeconomic differences that vary on the state level because macroeconomic conditions vary across federal states in Germany (IDW (2012)).
} 
randomly — they are more likely when banks are in trouble, a condition not necessarily observable to the econometrician. Naïve regressions that ignore these issues may yield biased coefficients. We use instruments, described in Section 2.3, to deal with this problem.

First-stage estimates are obtained using linear probability models for regulatory interventions and capital support, respectively. In the second stage, we regress changes in liquidity creation $(\Delta$ (LC/Total assets) $)$ or its components ( $\Delta$ (LC asset side/Total assets)), ( $\Delta$ (LC liability side/Total assets)), and ( $\Delta$ (LC off-balance sheet/Total assets)) on the predicted values of the potentially endogenous explanatory variables, controls, and banking pillar, year, and state dummies.

\subsection{Potentially endogenous explanatory variables}

We use a regulatory interventions dummy to capture the disciplinary actions by regulators described in Section 1.2. This variable takes the value one if one or more interventions took place in year $t-1$ and zero otherwise. We use a capital support dummy that takes the value one if support was provided in year $t-1$ and zero otherwise.

\subsection{Instruments}

Our identification strategy relies on three plausibly exogenous instruments. The identifying assumption is that our instruments affect the probabilities of regulatory interventions and capital support, but do not directly affect liquidity creation or the other outcomes studied. The instruments exploit in several dimensions information asymmetries among banks, regulators, and bankers associations' insurance schemes that are crucially driven by geography. This strategy reflects that most banks operate in geographically delimited banking markets. Consequently, we constrain the sample for the main analyses to banks in delimited markets to leverage the power of our instruments, although our findings are unaffected when we include banks that operate nationwide.

\subsubsection{Vote share of pro-business parties in parliamentary state elections}

Our first instrument is the most recent state vote share of pro-business parties, measured as the 
combined vote share of parties that are favorably orientated towards businesses in parliamentary elections at the state level. The motivation behind this instrument is based on Dam and Koetter (2012), who show that state level election outcomes matter for bank rescues in Germany. State parliamentary elections typically coincide with the county elections in each state and the results of elections for the members of the state legislature therefore closely resemble the variation in the electorate's propensity to support pro-business parties at the county level. This is reflected in a high correlation of 0.81 ( $p$-value 0.00 ) between the vote shares for pro-business parties at the state and county levels. Moreover, from an exogeneity perspective, relying on the state vote share rather than the county level vote share is more appropriate as the votes cast on the state level are less influenced by local banking conditions in the particular county where the distressed bank is located.

To construct this instrument, we consider conservative (CDU/CSU), liberal (FDP), and green parties (Bündnis 90/Die Grünen) as pro-business parties, and aggregate their percentage vote share in parliamentary state elections. They differ ideologically from social democratic parties (SPD), the left party (Die Linke), and others because conservatives, liberals, and greens represent interests of the upper-middle class, employers, and the business community, whereas social democrats, leftists, and others focus on protection of the labor force and redistribution of income.

Election outcomes play a crucial role for regulatory interventions because the Bundesbank's executive board and the BaFin's executive officers are appointed by the Federal President following nomination by politicians at the state and federal level. Partisan orientation of elected politicians at the state level should therefore influence the behavior of regulators for several reasons.

First, the economics literature on appointed regulators argues that politicians adopt policies in line with the interests of stakeholders to increase their chances of re-election (Grossman and Helpman, 1994; Botero, Djankov, LaPorta, and Lopez-De-Silanes, 2004). This literature shows that electoral incentives make politicians respond to stakeholder interests because voters are 
stakeholders in the regulated firms. Ultimately, regulatory actions become bundled with other policy issues for which the appointing politicians are responsible (Besley and Coate, 2003). Second, while the BaFin ultimately issues the regulatory intervention, the Bundesbank is involved throughout the process. Most importantly, the heads of supervision from the regional Bundesbank office in whose business area the distressed bank is located critically influence the decision of whether or not to intervene, and these supervisors are appointed by the executive board of the Bundesbank. Both arguments suggest that pro-business oriented politicians are likely to nominate candidates for the Bundesbank executive board whose views are in line with party ideology. ${ }^{10}$ The banking community represents some core constituents of the pro-business parties. It is therefore in the interest of these parties to preserve banks as a going concern, one of the key considerations behind issuing regulatory interventions since they reduce the likelihood of bank closures. We therefore anticipate that a greater share of pro-business parties increases the probability of observing regulatory interventions.

Notably, while this instrument is not bank-specific, three characteristics make it appealing for our research. First, it varies across states and over time as parliamentary elections at the state level take place at different times in different states. Their timing is dictated by an exogenous rule that varies for each state between four and five years. Second, it is correlated with the county-level support for pro-business parties. Third, the instrument adequately reflects that all banks in Germany, except for the largest banks which are excluded from our sample, operate in local markets. This geographical feature of the German banking system facilitates identification. It is unlikely that four- and five-year cycles of voting patterns at the state level correlate with annual

\footnotetext{
${ }^{10}$ Election outcomes may also influence the decisions of bankers associations' insurance schemes to provide capital support, albeit to a lesser extent. Behn, Haselmann, Kick, and Vig (2014) document that politicians are represented on the boards of insurance schemes in one pillar, the public-banking sector. This allows them to influence the scheme's decision to provide capital support. However, the effect is likely to be marginal for capital support relative to regulatory interventions as politicians can at best only influence capital support in one pillar.
} 
changes in the outcomes we study, given that the banks in our sample operate in small local markets. In short, our instrument provides plausibly exogenous variation in ideology and partisan orientation of politicians involved in the nomination of members of the executive board at the Bundesbank which is unrelated to contemporaneous changes of banks' liquidity creation.

\subsubsection{Distance between the bank and the bankers association's insurance scheme}

Our second instrument is the distance in kilometers $(\mathrm{ln})$ between the bank's headquarters and the corresponding bankers association's provider of insurance. The average (median) bank is located 252 (379) km away from its insurance provider. This further capitalizes on the characteristics of the German banking system where geography and the associated information asymmetries between the bank and the authorities play a major role, and where regulators and the bankers associations' insurance schemes independently monitor bank conduct.

The reasoning for this instrument is as follows. First, various papers (e.g., Coval and Moskowitz, 2001; Hau, 2001; Degryse and Ongena, 2005) establish that geographical proximity reduces information asymmetries. Information asymmetries matter because they impede surveillance activities by the bankers associations' insurance schemes. Sensitive information about bank soundness is more likely to be detected when monitoring agencies are located near the bank. ${ }^{11}$ Second, transportation costs also play a role for monitoring intensity because they increase in the distance between the bank and its insurer. Such costs impede effective monitoring of banks located further away from their insurance scheme, and monitoring resources may be allocated more towards firms in close proximity. In particular, for smaller insurance schemes, resource constraints may play a role for the allocation of monitoring activities. Thus, proximity increases the likelihood that the insurer identifies ailing institutions and provides capital support. Third, the Bundesbank and the

\footnotetext{
${ }^{11}$ Evidence on the monitoring behavior of the Securities and Exchange Commission (SEC) in the U.S. supports our argument. SEC monitoring is reduced when firms are located far away from an SEC office (Kedia and Rajgopal, 2011).
} 
BaFin are aware of the monitoring activities of the bankers associations' insurance schemes, and they may compensate for the reduced monitoring of faraway banks via more regulatory interventions. In other words, a greater distance from the location of the insurance scheme is likely to decrease the likelihood of capital support but increase the probability of regulatory interventions. Indeed, our summary statistics illustrate that the average distance to the insurer is shorter for banks with capital support $(317 \mathrm{~km})$ than it is for banks with regulatory interventions $(368 \mathrm{~km})$.

This instrument has further advantages. First, unlike the vote share variable, this instrument is bank-specific. Second, it is clearly exogenous with respect to contemporaneous changes in bank liquidity creation because it is time-invariant and therefore cannot correlate in an unobserved manner with the outcomes we study. In fact, for most banks, their location choices date back to the $19^{\text {th }}$ century, and insurance systems have been in place for decades, starting in the cooperative sector after the Great Depression. For private-sector and public-sector banks, insurance has existed since 1966 and 1969, respectively (Deutsche Bundesbank, 1992).

\subsubsection{Availability of a possible acquirer for distressed institutions}

Our third instrument gauges the likelihood that an ailing bank is acquired by another institution. Similar to the U.S. and elsewhere, distressed banks in Germany are often acquired by healthy institutions. However, what is important in our context is that such acquisitions can be arranged by bankers associations, but not by the BaFin or the Bundesbank, and legal requirements guide the choice of potential acquirers. Given this prominent role of private-sector arrangements for resolving troubled banks in Germany, we anticipate that the availability of a possible acquirer decreases the probability of regulatory interventions and reduces the need for capital support.

The scope for acquisitions is limited in Germany. State laws for savings banks and the ownership structure of cooperative banks restrict these banks' ability to merge with banks from other pillars. In addition, the regional principle to which these banks adhere requires that these 
banks only merge with other banks in their administrative district. These restrictions do not apply to private-sector banks, public-sector Landesbanks, and central cooperative banks. Possible acquirers for those institutions can be located anywhere in Germany. Moreover, economic intuition suggests that banks' ability to acquire a troubled bank is conditional on the acquirers' own profitability and capitalization. These time-varying characteristics and the legal provisions for acquisitions generate variation in the availability of acquirers that is unrelated to contemporaneous changes in liquidity creation of distressed banks that we can exploit for our identification strategy.

Construction of the instrument is as follows. First, for each bank in the sample, we identify potential acquirers by searching for potential healthy acquirers, defined as institutions with above median return on assets and capital adequacy in the same pillar that satisfy the location restrictions, if any, described above. Second, we restrict the set of possible acquirers and keep the largest bank in terms of total assets. Third, for each sample bank, we calculate the size difference between the largest possible acquirer and the bank itself, and express the resulting instrumental variable as a proportion of total assets of the bank itself. We thus end up with a narrow subset of banks that satisfy not only financial criteria that make an acquisition economically viable but also meet the legal provisions of the regulatory framework to acquire another bank. ${ }^{12}$

The higher the value of this variable, the greater is the likelihood that an institution will be taken over to be restructured and thus, the smaller is the probability that it receives regulatory interventions or capital support. This instrument is bank-specific and varies over time.

\subsection{Control variables}

\footnotetext{
${ }^{12}$ To illustrate how we construct the instrument, focus on a savings bank in the administrative district Upper Bavaria. To identify possible acquirers, we limit attention to all savings banks in Upper Bavaria that satisfy the location criterion. Among these, we identify savings banks with return on assets and capital adequacy above the median, and view the largest one to be the potential acquirer. The instrument is the size of this potential acquirer minus the size of the savings bank, normalized by the size of the savings bank. Computations are similar for cooperative banks. For private-sector banks, Landesbanks, and central credit cooperatives we drop the location criterion as there are no restrictions on the acquirer's location.
} 
Our regressions contain several control variables, which are lagged by one year. We express all financial variables in real $€$ (year 2000) using a GDP deflator from the Federal Statistical Office.

$\Delta$ Total assets (ln) accounts for changes in bank size. $\Delta$ Return on equity controls for changes in profitability. $\Delta$ Loan portfolio concentration is the change in a Herfindahl-Hirschman index (HHI) of lending activities across eight industries. $\Delta$ Fee income, the ratio of fee income to total income, focuses on non-traditional banking activities to capture changes in the business mix. Local output growth in each bank's market controls for local demand-side effects. This variable is measured at the county level. Tier 1 capital to total assets and Nonperforming loans to total loans enter in levels and capture the bank's financial condition. Distance to the nearest metropolitan area $(\mathrm{km}, \mathrm{ln})$ measures the distance between the bank's headquarters and the closest metropolitan area in the federal state.

The regressions also include banking pillar, year, and state dummies. Pillar dummies, which are highly correlated with bank size, account for differences in business models and ownership structures (private-sector dummy is omitted to avoid perfect collinearity). ${ }^{13}$ Moreover, the inclusion of banking pillar dummies also helps capture institutional differences in the respective pillar. Year dummies capture effects that vary over time but affect all banks equally in a given year such as demand conditions and regulations. As discussed above, state dummies net out time-invariant omitted variables that affect liquidity creation of all banks in the same state.

\subsection{Data}

We obtain annual data for all banks operating in Germany between 1999 and 2009, and augment these with data about regulatory interventions and capital support, all provided by the Bundesbank. We impose standard screens and exclude banks if they have: i) no loans outstanding; ii) zero

\footnotetext{
${ }^{13}$ Cooperative banks are by far the smallest institutions, followed by public sector banks and private banks. This is particularly so for the largest banks in each pillar: at the $90^{\text {th }}$ percentile, cooperative banks / savings banks / private banks have a size of $€ 719$ million / $€ 3,680$ million / $€ 8,350$ million, respectively.
} 
deposits; or iii) balance sheet items with negative values. We treat acquisitions in the conventional way: the acquirer continues with its identifier post-acquisition. We drop the year of the acquisition

to avoid artificial spikes in liquidity creation. Applying these restrictions results in a dataset with 17,473 bank-year observations for 2,521 banks. To refine identification, we constrain the dataset to banks whose operations can be assigned to local banking markets. This results in a sample of 17,342 bank-year observations for 2,501 banks. Table I contains summary statistics.

\section{Results}

\subsection{Main results}

\subsubsection{First-stage results: Instruments}

Our two first-stage regressions in Table II Panel A analyze the determinants of regulatory interventions and capital support. The three instruments are significant with the predicted signs in five of six cases, supporting the economic rationale underlying them.

First, the distance to the bankers associations' insurer is significant for capital support with a negative sign and it is positive for regulatory interventions, highlighting the complementarity between the actions of the insurance schemes and the regulators. Second, a higher vote share of probusiness parties has a significant positive correlation with the likelihood of regulatory interventions, supporting our hypothesis. The finding that the vote share of pro-business parties enters with the expected sign but remains insignificant for capital support is in line with our argument that the vote share plays at best a minor role for capital support. Third, the availability of a possible acquirer significantly reduces the need for regulatory interventions and capital support, supporting the argument that the legal provisions that limit the choice of acquisition candidate matter.

Most of the control variables have expected signs and are significant.

\subsubsection{Second-stage results: Regulatory interventions and capital support}

Our second-stage results, also in Table II Panel A, show that banks significantly reduce their 
liquidity creation in response to regulatory interventions, but not to capital support. The results are economically significant. The average bank contracts liquidity creation normalized by total assets by 9.8 percentage points after regulatory interventions, which is large relative to the mean of $22.3 \% .{ }^{14}$ The signs on the control variables in the second stage are intuitive.

Our specification so far uses all bank-years for banks that operate in local markets. However, typically only banks that are identified by regulators and bankers associations as potentially needing regulatory interventions and capital support are subjected to such actions. We therefore investigate subsamples of healthy and unhealthy banks. Absent an official list of unhealthy banks in Germany, we define banks that are at or below (above) the median equity ratio as unhealthy (healthy).

Such a test is also useful to illustrate the validity of our instruments. Not only are unhealthy institutions likely to respond more strongly to the actions of interest, but finding that the instruments strongly predict capital support in the first stage for healthy banks would question our results since capital support is typically only provided to banks with weak capital positions. In contrast, banks in both subsamples may be subject to regulatory interventions, so we do not have specific predictions for the first stage for regulatory interventions.

Table II Panel B reports the results. The first-stage results for regulatory interventions have no clear pattern across the two subsamples, as expected. The results for capital support show that none of the three instruments has predictive power for healthy banks, supporting our identification strategy. The second-stage results for regulatory interventions are significant only for unhealthy banks and this effect (13.4 percentage points) is greater in magnitude than for the full sample.

\footnotetext{
${ }^{14}$ We perform various robustness checks (available upon request). Results are similar when replacing state dummies with market fixed effects (defined by county borders) to deal with unobserved factors that affect all banks operating in local markets equally. Results are also comparable when including nationally active banks. In addition, reductions in local loan demand, approximated by contractions in local output growth, do not affect our inferences. Changes in governance structure such as executive turnovers, banks' anticipation of authorities' actions, or poor performance also do not drive the results.
} 
Consistent with the main result, the effect of capital support is insignificant in both subsamples.

\subsubsection{Instrument strength and overidentification restrictions}

It is critical that our instruments are econometrically strong because weak instruments can lead to worse biases than OLS. We therefore report the standard $F$-statistic of excluded instruments and also show the Angrist-Pischke multivariate $F$-statistic, which tests whether individual endogenous regressors are weakly identified. Both statistics are significant, so we reject the null that our instruments are weak. To examine the overidentification restrictions, we present Hansen $J$-statistics. These diagnostics are statistically indistinguishable from zero, suggesting that the three instruments are correctly excluded from the second-stage equation.

\subsection{Components of liquidity creation and selected drivers}

We have already shown that regulatory interventions reduce liquidity creation, but it is interesting to understand where these adjustments take place: on the asset side, the liability side, or off the balance sheet. We therefore now decompose liquidity creation into these three components, and regress changes in asset-side, liability-side, and off-balance sheet liquidity creation (all normalized by total assets) on regulatory interventions, capital support, and our other explanatory variables.

Table III Panel A illustrates that regulatory interventions only reduce liquidity creation on the liability side (by 5.4 percentage points) and off the balance sheet (by 4.5 percentage points). Instead of altering their asset portfolios, banks respond to the interventions primarily by adjusting their funding and off-balance sheet activities.

This analysis yields another insight. Capital support reduces asset-side liquidity creation by an economically significant amount (10.6 percentage points) and increases liability-side liquidity creation by a similar amount (8.1 percentage points). These effects thus cancel each other out, explaining why we find no overall effect of capital support on total liquidity creation. There is no significant measured effect of capital support on off-balance sheet liquidity creation. 
Table III Panel B repeats these tests, splitting the sample at the median equity ratio to examine whether the components of liquidity creation respond differently at banks with relatively high or low capital ratios. Regulatory interventions have again no effect on the asset side, and they affect the liability side only at banks with equity ratios below the median. Regulatory interventions significantly affect off-balance sheet liquidity creation in both subsamples. As expected, capital support only affects liquidity creation on the asset side of banks with equity ratios below the median. On the liability side, the effects are significant for both subsamples, but the statistical significance declines. Capital support does not affect off-balance sheet liquidity creation.

The result above that capital injections cause asset-side liquidity creation to contract warrants more discussion. First, and as mentioned in the Introduction, theories are split on the role of bank capital for liquidity creation. Some posit a negative effect. Diamond and Rajan (2000) argue that capital hampers liquidity creation because it reduces depositor monitoring necessary for liquidity creation. Gorton and Winton (2000) argue that capital reduces liquidity creation because it crowds out deposits, a key source of liquidity creation. Other theories collectively suggest that higher capital improves banks' ability to create liquidity. One set argues that liquidity creation exposes banks to liquidity risk (e.g., Allen and Santomero, 1998; Allen and Gale, 2004), while another posits that capital absorbs risk and expands banks' risk-bearing capacity (e.g., Bhattacharya and Thakor, 1993; Repullo, 2004; von Thadden, 2004), so higher capital ratios may enable banks to create more liquidity. Donaldson, Piacentino, and Thakor (2015) does not fall in either group, but shows that higher capital incentivizes banks to work harder, leading to more lending and liquidity creation. Our results lend support to the theories that predict a negative effect of capital on (assetside) liquidity creation. Our results are also in line with the evidence for small banks in other countries: the U.S. (Berger and Bouwman, 2009), Russia (Fungacova, Weill, and Zhou, 2010), China (Lei and Song, 2013), and the Czech Republic (Horvath, Seidler, and Weill, 2014). 


\subsection{Extensions: Lending activities and risk taking}

We also investigate asset-side liquidity creation from a different perspective by looking directly at lending. Table IV examines changes in total loans and the two main lending categories: corporate loans and retail loans (both scaled by total assets). We find that regulatory interventions have no effect on lending, which is consistent with the result that such interventions do not affect asset-side liquidity creation. In contrast, capital support reduces total loans by 15.2 percentage points, consistent with our result that capital support reduces asset-side liquidity creation. The effect is greater for corporate loans (11.1 percentage points) than for retail loans (4.7 percentage points).

We next examine whether regulatory interventions and capital support reduce bank risk taking, one of the main goals of these actions. We focus on two widely used and complementary bank risk taking measures: changes in log-transformed Z-Scores $(\Delta \mathrm{Z}$-Score $(\ln ))$, where the ZScore is computed as return on assets (ROA) plus the capital ratio divided by the standard deviation of ROA, and changes in the ratio of risk-weighted assets to total assets ( $\Delta$ (RWA/Total assets)). Our results show that Z-Scores (ln) increase by 2.7 whereas risk-weighted asset ratios decline by 15.0 percentage points, both suggesting declines in risk taking. Importantly, capital support now enters significantly with intuitive effects: it increases Z-Scores (ln) by 3.8 percentage points and reduces risk-weighted asset ratios by 10.5 percentage points. These tests highlight that capital support plays a crucial part for banks' incentives to take risk, in line with theory showing that capital reduces asset-substitution moral hazard (e.g., Morrison and White, 2005) and strengthens banks' monitoring incentives (e.g., Allen, Carletti and Marquez, 2011; Mehran and Thakor, 2011).

\subsection{Different types of regulatory interventions}

It is important to understand whether all types of regulatory interventions trigger similar effects, or, alternatively, if more severe interventions cause greater changes in conduct than moderate interventions. It is also useful to evaluate if the changes in liquidity creation are due to restrictions 
and prohibitions of business activities or due to interventions that are directly aimed at bank management. To address these issues, we split the regulatory interventions along these dimensions.

Table V Panel A focuses on moderate versus severe interventions. The coefficient on severe regulatory interventions is more than twice as large as that for moderate interventions, showing significant decreases in liquidity creation by 27.9 and 11.1 percentage points, respectively. Splitting liquidity creation into its components, both moderate and severe interventions play no role on the asset side, but they do reduce liquidity creation on the liability side and off the balance sheet.

Table V Panel B focuses on interventions that affect business activities versus management. Interventions aimed at business activities do not significantly affect liquidity creation or its components, except that they reduce off-balance sheet liquidity creation. However, interventions aimed at management are the driving force behind the observed declines in liquidity creation and its liability-side and off-balance sheet components. Neither interventions aimed at business activities nor those aimed at management affect liquidity creation on the asset side of the balance sheet.

\subsection{Long-run effects}

We have so far focused on the short run, i.e., the effects in the year after regulatory interventions and capital support. Natural questions that arise are whether the adjustments in bank behavior take longer than a year to be implemented and whether these effects persist or are subsequently reversed.

We now examine the effects of both actions on liquidity creation and its components in the long run. These IV regressions are similar to the main regressions with the only difference being that we lag the explanatory variables by 2,3 , or 4 years instead of 1 year. We do not include lags of multiple lengths in the same regression because of the dearth of available instruments. Table VI shows that none of the longer lags is significant. This suggests that the effects of regulatory interventions and capital support materialize quickly and are not reversed in subsequent years.

\section{Concluding remarks}


When banks are troubled, authorities often issue regulatory interventions and/or provide capital support (bailouts). While the main goal of such actions is to reduce banks' risk taking to restore safe and sound operations, these actions may have the unintended effect of reducing liquidity creation, which may adversely affect the real economy. The focus of this paper is to study the effects of authorities' actions on liquidity creation.

Using a unique dataset from Germany and relying on three plausibly exogenous instruments, we find that regulatory interventions reduce liquidity creation, while capital support does not affect liquidity creation. Further investigation suggests that regulatory interventions do not affect liquidity creation on the asset side of the balance sheet, but they do affect liquidity creation on the liability side and off the balance sheet. Capital support has no effect on off-balance sheet liquidity creation but reduces asset-side and increases liability-side liquidity creation by roughly the same magnitude, effectively canceling out each other. We also show that regulatory interventions have no effect on lending, a key component of asset-side liquidity creation, but capital support triggers declines in lending. As expected, both regulatory interventions and capital support reduce bank risk taking.

Our findings that capital support reduces lending and risk taking differ from some of the U.S. TARP studies, which report mixed results. Differences between the U.S. and Germany may explain these dissimilar results. First, capital support under the TARP program took place only during the recent crisis, while our sample spans both crisis and non-crisis periods. Second, in contrast to the U.S. where capital support draws on taxpayer money, it is predominantly private parties in the form of bankers associations' insurance schemes that provide capital support in Germany. The U.S. is moving more in this direction. Under Dodd-Frank, taxpayers will no longer be responsible for the costs of resolving systemically important financial institutions (SIFIs). This cost will be borne by other SIFIs. Our study sheds new light on how the design features of bank resolution mechanisms can involve private parties to limit the adverse consequences for taxpayers. 


\section{References}

Aghion, P., P. Bolton, and S. Fries, 1999, Optimal design of bank bailouts: The case of transition economies, Journal of Institutional and Theoretical Economics 155: 51-70.

Allen, F., E. Carletti, and R. Marquez, 2011, Credit market competition and capital regulation, Review of Financial Studies 24: 983-1018.

Allen, F., and D. Gale, 2004, Financial intermediaries and markets, Econometrica 72: 1023-1061.

Allen, F., and A. Santomero, 1998, The theory of financial intermediation, Journal of Banking and Finance 21: 1461-1485.

Babajide Wintoki, M. B., J. S. Linck, and J. M. Netter, 2012, Endogeneity and the dynamics of internal corporate governance, Journal of Financial Economics 105: 581-606.

Barth, J. R., G. Caprio Jr., and R. Levine, 2004, Bank regulation and supervision: What works best?, Journal of Financial Intermediation 13: 205-248.

Bayazitova, D., and A. Shivdasani, 2012, Assessing TARP, Review of Financial Studies 25: 377-407.

Behn, M., R. Haselmann, T. Kick, and V. Vig, 2014, The political economy of bank bailouts, Working Paper, Goethe University, Frankfurt am Main.

Berger, A. N., and C. H. S. Bouwman, 2009, Bank liquidity creation, Review of Financial Studies 22: 3779-3837.

Berger, A. N., and C. H. S. Bouwman, 2013, How does capital affect bank performance during financial crises?, Journal of Financial Economics 109: 146-176.

Berger, A. N., and C. H. S. Bouwman, 2015, Bank liquidity creation, monetary policy, and financial crises, working paper.

Berger, A. N., M. K. Kyle, and J. M. Scalise, 2001, Did U.S. bank supervision get tougher during the credit crunch? Did they get easier during the banking boom? Did it matter to bank lending? In: F. Mishkin, Ed. Prudential Supervision: What works and what doesn't? Chicago, IL: University of Chicago Press.

Berger, A. N., and R.A. Roman, 2015, Did saving Wall Street really save main street? The real effects of TARP on local economic conditions, Working paper.

Berger, A. N., and G. F. Udell, 1994, Did risk-based capital allocate bank credit and cause a 'credit crunch' in the United States?, Journal of Money, Credit, and Banking 26: 585-628.

Besley, T., and S. Coate, 2003, Elected versus appointed regulators: Theory and evidence, Journal of the European Economic Association 1: 1176-1206.

Bhattacharya, S., and K. G. Nyborg, 2013, Bank bailout menus, Review of Corporate Finance Studies 2: 29-61.

Bhattacharya, S., and A. V. Thakor, 1993, Contemporary banking theory, Journal of Financial Intermediation 3: 2-50.

Bizer, D. S., 1993, Regulatory discretion and the credit crunch, Working Paper, U.S. Securities and Exchange Commission, Washington DC, April.

Black, L. K., and L. N. Hazelwood, 2013, The effect of TARP on bank risk-taking, Journal of Financial Stability 9: 790-803.

Bonaccorsi di Patti, E., and E. Sette, forthcoming, Did the securitization market freeze affect bank lending during the financial crisis? Evidence from a credit register, Journal of Financial Intermediation.

Boot, A. W. A., and A. V. Thakor, 1993, Self-interested bank regulation, American Economic Review 83: 206-212.

Botero, J., S. Djankov, R. LaPorta, and F. C. Lopez-De-Silanes, 2004, The regulation of labor, Quarterly Journal of Economics 119: 1339-1382.

Brown, C. O., and S. Dinc, 2005, The politics of bank failures: Evidence from emerging markets, Quarterly Journal of Economics 120: 1413-1444. 
Brunner, A., J. Decressin, D. Hardy, and B. Kudela, 2004, Germany's three-pillar banking system cross-country perspectives in Europe, Working paper International Monetary Fund, Washington DC, Occasional Paper No. 233.

Cornelli, F., Z. Kominek, and A. Ljungqvist, 2013, Monitoring managers: Does it matter?, Journal of Finance 68: 431-481.

Coval, J. D., and T. J. Moskowitz, 2001, The geography of investment: Informed trading and asset prices, Journal of Political Economy 109: 811-41.

Dam, L., and M. Koetter, 2012, Bank bailouts and moral hazard: Evidence from Germany, Review of Financial Studies 25: 2343-2380.

Degryse, H. and S. Ongena, 2005, Distance, lending relationships and competition, Journal of Finance 60: 231-266.

Delis, M., and P. Staikouras, 2011, Supervisory effectiveness and bank risk-taking, Review of Finance 15, 511-543.

Delis, M., C. Tsoumas, and P. Staikouras, 2013, Enforcement actions and bank behavior, MPRA Paper No. 43557.

Demirgüç-Kunt, A., E. Detragiache, and T. Tressel, 2008, Banking on the principles: Compliance with Basel Core Principles and bank soundness, Journal of Financial Intermediation 17: 511-542.

Deutsche Bundesbank, 1992, Deposit protection schemes in the Federal Republic of Germany, Monthly Report of the Deutsche Bundesbank, July 1992.

Diamond, D. W., and R. G. Rajan, 2000, A theory of bank capital, Journal of Finance 55: 2431-2465.

Donaldson, J., G. Piacentino, and A. V. Thakor, 2015, Warehouse banking, Working paper.

Duchin, R., and D. Sosyura, 2012, The politics of government investment, Journal of Financial Economics 106: 24-48.

Duchin, R., and D. Sosyura, 2014, Safer ratios, riskier portfolios: Banks' response to government aid, Journal of Financial Economics 113: 1-28.

Dwyer, G. P., and I. Hasan, 2007, Suspension of payments, bank failures, and the nonbank public's losses, Journal of Monetary Economics 54: 565-580.

Ellul, A., and V. Yerramilli, 2013, Stronger risk controls, lower risk: Evidence from U.S. bank holding companies, Journal of Finance 68: 1757-1803.

Ennis, H. M., and T. Keister, 2010, Banking panics and policy responses, Journal of Monetary Economics 57: 404-419.

Fischer, M., C. Hainz, J. Rocholl, and S. Steffen, 2012, Government guarantees and bank risk taking incentives. AFA 2012 Chicago Meetings Paper.

Fungacova, Z., L. Weill, and M. Zhou, 2010, Bank capital, liquidity creation, and deposit insurance, BOFIT Discussion Papers, Bank of Finland 17/10.

Giannetti, M., and A. Simonov, 2013, On the real effects of bank bailouts: Micro evidence from Japan, American Economic Journal: Macroeconomics 5: 135-67.

Gropp R., C. Gruendl, and A. Guettler, 2014, The impact of public guarantees on bank risk taking: Evidence from a natural experiment, Review of Finance 18: 457-488.

Gropp, R., H. Hakenes, and I. Schnabel, 2011, Competition, risk shifting, and public bailout policies, Review of Financial Studies 24: 2084-2120.

Grossman, G. M., and E. Helpman, 1994, Protection for sale, American Economic Review 84: 833-850. Hau, H., 2001, Location matters: An examination of trading profits, Journal of Finance 56: 1959-1983.

Hennessy, C., and T. M. Whited, 2007, How costly is external financing? Evidence from a structural estimation, Journal of Finance 62: 1705-1745.

Horvath, R., J. Seidler, and L. Weill, 2014, Bank capital and liquidity creation: Granger causality evidence, Journal of Financial Services Research 45, 341-361. 
Houston, J., and C. James, 1993, Management and organizational changes in banking: a comparison of regulatory intervention with private creditor actions in nonbank firms, Carnegie-Rochester Conference Series on Public Policy 38: 143-178.

Institut der deutschen Wirtschaft, 2012, Zehntes Bundesländerranking: Bundesländer im Vergleich Wer wirtschaftet am besten? Institut der deutschen Wirtschaft Köln.

James, C., 1991, The losses realized in bank failures, Journal of Finance 46: 1223-1242.

Kedia, S., and S. Rajgopal, 2011, Do the SEC's enforcement preferences affect corporate misconduct? Journal of Accounting and Economics 51: 257-278.

Kick, T., M, Koetter, and T. Poghosyan, 2010, Recovery determinants of distressed banks: regulators, market discipline, or the environment?, IMF Working Paper 10/27, International Monetary Fund.

Kiser, E. K., R. A. Prager, and J. R. Scott, 2012, Supervisor ratings and the contraction of bank lending to small businesses. Federal Reserve Board Discussion Paper 2012-59.

Lei, A. C. H, and Z. Song, 2013, Liquidity creation and bank capital structure in China, Global Finance Journal 24, 188-202.

Li, L., 2013, TARP funds distribution and bank loan supply, Journal of Banking and Finance 37: 4777-4792.

MacKay, P., 2003, Real flexibility and financial structure: An empirical analysis, Review of Financial Studies 16: 1131-1165.

Mailath, G. J., and L. J. Mester, 1994, A positive analysis of bank closure. Journal of Financial Intermediation 3: 272-299.

Mehran, H., and A. V. Thakor, 2011, Bank capital and value in the cross-section, Review of Financial Studies 24: 1019-1067.

Morrison, A. D., and L. White, 2005, Crises and capital requirements in banking. American Economic Review 95: 1548-1572.

Nini, G., D. C. Smith, and A. Sufi, 2012, Creditor control rights, corporate governance, and firm value. Review of Financial Studies 25: 1713-1761.

Peek, J., and E. Rosengren, 1995, The capital crunch: Neither a borrower nor a lender be. Journal of Money, Credit, and Banking 27: 625-638.

Philippon, T., and P. Schnabl, 2013, Efficient recapitalization, Journal of Finance 68: 1-42.

Repullo, R., 2004, Capital requirements, market power, and risk-taking in banking, Journal of Financial Intermediation 13: 156-182.

Samolyk, K. A., 1994, Banking conditions and regional economic performance: Evidence of a regional credit channel, Journal of Monetary Economics 34: 259 -278.

Thakor, A. V. 1996, Capital requirements, monetary policy, and aggregate bank lending: theory and empirical evidence, Journal of Finance 51: 279-324.

von Thadden, E.-L., 2004, Bank capital adequacy regulation under the new Basel Accord, Journal of Financial Intermediation 13: 90-95.

Wooldridge, J. M., 2002, Econometric analysis of cross section and panel data. MIT Press. 


\section{Table I: Summary statistics}

We present summary statistics for dependent variables, potentially endogenous explanatory variables, instruments, control variables, and pillar dummies. While regressions are run in changes (excep for the dummies, including the potentially endogenous explanatory variables; the instruments; the Tier 1 capital ratio; the nonperforming loans ratio; and the distance to the nearest metropolitan area), we report summary statistics for the levels of all the variables for ease of interpretation. Panel A shows summary statistics for the full sample. Panels B, C, and D report these statistics for bank-years with regulatory interventions only, capital support only, and both types of actions in the previous year, respectively. All of the ratios are expressed in percentage terms (\%). Liquidity creation is alternatively defined as the Mat Cat Fat measure, which includes off-balance sheet activities (see Appendix A), and its three components (asset-side, liability-side, and off-balance sheet liquidity creation). All are scaled by total assets. Lending is measured as total loans, corporate loans, and retail loans, all scaled by total assets. Risk is measured as the Z-Score (ln) and the ratio of riskweighted assets to total assets. The potentially endogenous explanatory variables are: regulatory interventions (dummy) and capital support (dummy). They are instrumented by: the state vote share of pro-business parties (\%); the distance between the bank and its bankers association's provider of insurance ( $\mathrm{km}, \mathrm{ln})$; and the availability of a possible acquirer (\%). The control variables include: tota assets $(€, \ln )$; return on equity (operating income divided by equity capital); loan portfolio concentration (a Herfindahl-Hirschman index); fee income divided by total income; Tier 1 capital divided by total assets; nonperforming loans divided by total loans; local output growth; and distance to the nearest metropolitan area (km, ln). The regressions also include dummies for the public-sector and cooperative-sector pillars (the private-sector pillar dummy is excluded as the base case), year dummies, and state dummies. Summary statistics for year and state dummies are suppressed to save space.

\begin{tabular}{|c|c|c|c|c|c|c|c|c|c|c|c|c|}
\hline & \multicolumn{3}{|c|}{$\begin{array}{c}\text { Panel A: Full sample } \\
\text { (17,342 bank-year observations) }\end{array}$} & \multicolumn{3}{|c|}{$\begin{array}{c}\text { Panel B: Bank-years with } \\
\text { regulatory interventions in } \\
t \text {-1 } \\
\text { (448 bank-year observations) }\end{array}$} & \multicolumn{3}{|c|}{$\begin{array}{l}\text { Panel C: Bank-years with } \\
\text { capital support in } \boldsymbol{t} \mathbf{- 1} \\
\text { (357 bank-year observations) }\end{array}$} & \multicolumn{3}{|c|}{$\begin{array}{l}\text { Panel D: Bank-years with } \\
\text { regulatory interventions } \\
\text { and capital support in } t \text {-1 } \\
\text { (68 bank-year observations) }\end{array}$} \\
\hline & Mean & S.D. & Median & Mean & S.D. & Median & Mean & S.D. & Median & Mean & S.D. & Median \\
\hline \multicolumn{13}{|l|}{ Dependent variables } \\
\hline LC/Total assets $(\%)$ & 22.29 & 10.55 & 23.14 & 22.16 & 9.88 & 23.68 & 21.78 & 9.19 & 21.79 & 23.71 & 8.59 & 22.73 \\
\hline LC asset side/Total assets (\%) & 13.76 & 10.18 & 15.25 & 14.26 & 9.21 & 16.10 & 12.82 & 9.54 & 13.80 & 14.77 & 7.86 & 14.16 \\
\hline LC liability side/Total assets (\%) & 5.82 & 4.01 & 5.178 & 5.10 & 3.04 & 4.72 & 6.43 & 4.00 & 6.34 & 6.52 & 3.73 & 6.40 \\
\hline LC off-balance sheet/Total assets (\%) & 2.62 & 1.85 & 2.167 & 2.74 & 1.86 & 2.24 & 2.48 & 1.47 & 2.19 & 2.46 & 1.52 & 2.11 \\
\hline Total loans/Total assets (\%) & 57.85 & 14.35 & 59.78 & 61.61 & 13.71 & 64.73 & 57.32 & 15.23 & 57.81 & 58.44 & 14.75 & 59.80 \\
\hline Corporate loans/Total assets (\%) & 26.23 & 9.75 & 25.96 & 30.87 & 9.98 & 30.85 & 30.05 & 9.85 & 29.70 & 33.05 & 9.96 & 31.57 \\
\hline Retail loans/Total assets (\%) & 31.42 & 11.47 & 31.73 & 30.66 & 9.05 & 31.51 & 27.13 & 11.57 & 26.59 & 25.39 & 7.91 & 25.8 \\
\hline Z-Score $(\ln )$ & 4.58 & 1.28 & 4.50 & 4.33 & 1.28 & 4.42 & 4.23 & 1.55 & 4.26 & 3.71 & 1.56 & 3.69 \\
\hline RWA/Total assets (\%) & 59.42 & 12.54 & 60.32 & 62.48 & 10.39 & 62.60 & 59.90 & 12.52 & 61.12 & 61.26 & 10.52 & 60.44 \\
\hline \multicolumn{13}{|l|}{ Potentially endogenous explanatory variables } \\
\hline Regulatory interventions (dummy) & 0.03 & 0.16 & 0 & 1 & 0 & 1 & 0 & 0 & 0 & 1 & 0 & 1 \\
\hline Capital support (dummy) & 0.02 & 0.14 & 0 & 0 & 0 & 0 & 1 & 0 & 1 & 1 & 0 & 1 \\
\hline \multicolumn{13}{|l|}{ Instruments } \\
\hline State vote share of pro-business parties $(\%)$ & 58.20 & 8.43 & 60.25 & 56.43 & 6.89 & 53.87 & 57.24 & 8.12 & 60.25 & 56.39 & 8.77 & 54.22 \\
\hline Distance to bankers association's insurer $(\mathrm{km}, \mathrm{ln})$ & 5.53 & 0.95 & 5.94 & 5.91 & 0.51 & 6.03 & 5.76 & 0.74 & 6.04 & 5.87 & 0.40 & 6.05 \\
\hline Availability of a possible acquirer $(\%)$ & 12.83 & 26.37 & 3.88 & 10.34 & 18.05 & 3.66 & 7.00 & 25.39 & 1.22 & 5.80 & 23.67 & 1.33 \\
\hline \multicolumn{13}{|l|}{ Control variables } \\
\hline Total assets $(€, \ln )$ & 19.57 & 1.36 & 19.49 & 19.24 & 1.17 & 19.18 & 19.80 & 1.03 & 19.62 & 19.74 & 1.05 & 19.85 \\
\hline Return on equity $(\%)$ & 4.50 & 3.68 & 4.214 & 3.75 & 4.09 & 3.55 & 1.65 & 4.26 & 2 & -0.61 & 5.97 & 1.75 \\
\hline Loan portfolio concentration (HHI) (\%) & 29.83 & 12.63 & 26.18 & 27.69 & 11.57 & 24.13 & 29.95 & 11.68 & 26.46 & 30.09 & 11.69 & 27.17 \\
\hline Fee income/Total income $(\%)$ & 12.64 & 5.45 & 11.85 & 12.48 & 4.32 & 12.31 & 13.30 & 4.84 & 12.78 & 14.16 & 4.24 & 13.77 \\
\hline Tier1 capital/Total assets (\%) & 5.677 & 1.67 & 5.39 & 5.28 & 1.33 & 5.04 & 5.08 & 1.51 & 4.79 & 4.80 & 1.40 & 4.57 \\
\hline Nonperforming loans/Total loans (\%) & 4.49 & 3.60 & 3.61 & 7.17 & 4.06 & 6.63 & 11.53 & 6.35 & 10.91 & 14.34 & 5.62 & 14.93 \\
\hline Local output growth (\%) & 1.87 & 3.32 & 1.82 & 1.52 & 3.04 & 1.29 & 1.81 & 2.79 & 1.72 & 1.10 & 3.91 & 0.74 \\
\hline Distance to nearest metropolitan area $(\mathrm{km}, \mathrm{ln})$ & 3.88 & 1.08 & 4.17 & 3.94 & 1.04 & 4.21 & 3.82 & 1.16 & 4.15 & 3.81 & 1.08 & 4.14 \\
\hline \multicolumn{13}{|l|}{ Dummies } \\
\hline Public-sector pillar (dummy) & 0.25 & 0.43 & 0 & 0.04 & 0.20 & 0 & 0.05 & 0.22 & 0 & 0 & 0 & 0 \\
\hline Cooperative-sector pillar (dummy) & 0.68 & 0.46 & 1 & 0.92 & 0.26 & 1 & 0.86 & 0.34 & 1 & 0.97 & 0.17 & 1 \\
\hline
\end{tabular}


Table II: Main results and sample split by equity ratio

This table shows IV regressions for the effects of regulatory interventions and capital support on liquidity creation ( $\Delta$ (LC/Total assets)). Panel A presents the results for the full sample, and Panel B presents the results for subsamples of banks, split at the median equity ratio. The potentially endogenous explanatory variables, regulatory interventions and capital support, are measured as dummies. As instruments we use: the state vote share of pro-business parties (\%); the distance between the bank and its bankers association's provider of insurance (km, ln); and the availability of a possible acquirer $(\%)$. The control variables include: $\Delta$ Total assets $(€, \ln ) ; \Delta$ Return on equity (operating income divided by equity capital) $(\%) ; \Delta$ Loan portfolio concentration (a Herfindahl-Hirschman index) (\%); $\Delta$ Fee income divided by total income (\%); Tier 1 capital divided by total assets (\%); and Nonperforming loans divided by total loans (\%); Local output growth; and the Distance to the nearest metropolitan area $(\mathrm{km}, \mathrm{ln})$. The regressions also include a constant, dummies for the public-sector and cooperative-sector pillars (the private-sector pillar dummy is excluded as the base case), year dummies, and state dummies (not shown for brevity). The regressions are run in changes (except for the dummies (including the potentially endogenous explanatory variables), the instruments, the

Tier 1 capital ratio, the Nonperforming loans ratio, and the Distance to the neatest major metropolitan area $(\mathrm{km}, \mathrm{ln})$ ). The potentially endogenous explanatory variables and control variables are lagged by one year. Robust z-statistics are in brackets. Standard errors are clustered at the bank level. *** $\mathrm{p}<0.01, * * \mathrm{p}<0.05, * \mathrm{p}<0.1$

\begin{tabular}{|c|c|c|c|c|c|c|c|c|c|}
\hline & \multirow{2}{*}{\multicolumn{3}{|c|}{ Panel A: Full sample }} & \multicolumn{6}{|c|}{ Panel B: Sample split by equity ratio } \\
\hline & & & & \multicolumn{3}{|c|}{ Equity ratio $\leq \mathrm{p} 50$} & \multicolumn{3}{|c|}{ Equity ratio $>$ p50 } \\
\hline & First-stage & First-stage & Second-stage & First-stage & First-stage & Second-stage & First-stage & First-stage & Second-stage \\
\hline Dependent variable & $\begin{array}{c}\text { Regulatory } \\
\text { interventions }\end{array}$ & $\begin{array}{l}\text { Capital } \\
\text { support }\end{array}$ & $\begin{array}{c}\Delta \text { (LC } \\
\text { /Total assets) }\end{array}$ & $\begin{array}{c}\text { Regulatory } \\
\text { interventions }\end{array}$ & $\begin{array}{l}\text { Capital } \\
\text { support }\end{array}$ & $\begin{array}{c}\Delta(\mathrm{LC} \\
\text { /Total assets) }\end{array}$ & $\begin{array}{c}\text { Regulatory } \\
\text { interventions }\end{array}$ & $\begin{array}{l}\text { Capital } \\
\text { support }\end{array}$ & $\begin{array}{c}\Delta \text { (LC } \\
\text { /Total assets) }\end{array}$ \\
\hline $\begin{array}{l}\text { Regulatory interventions } \\
\text { Capital support }\end{array}$ & & & $\begin{array}{c}-9.8215 * * \\
{[-2.05]} \\
-2.7828 \\
{[-0.66]}\end{array}$ & & & $\begin{array}{c}-13.4173^{* *} \\
{[-2.11]} \\
-1.2440 \\
{[-0.31]}\end{array}$ & & & $\begin{array}{c}-6.4424 \\
{[-0.91]} \\
-0.8351 \\
{[-0.09]}\end{array}$ \\
\hline Distance to bankers association's insurer $(\mathrm{km}, \mathrm{ln})$ & $\begin{array}{c}0.0041 * * \\
{[2.14]}\end{array}$ & $\begin{array}{c}-0.0052 * * \\
{[-2.08]}\end{array}$ & & $\begin{array}{l}0.0064 \\
{[1.39]}\end{array}$ & $\begin{array}{l}0.004 \\
{[1.48]}\end{array}$ & & $\begin{array}{c}0.0009 * * * \\
{[3.53]}\end{array}$ & $\begin{array}{l}0.0011 \\
{[0.86]}\end{array}$ & \\
\hline State vote share of pro-business parties (\%) & $\begin{array}{c}0.0015^{* * *} \\
{[5.03]}\end{array}$ & $\begin{array}{l}0.0001 \\
{[0.42]}\end{array}$ & & $\begin{array}{c}0.0017 * * * \\
{[3.58]}\end{array}$ & $\begin{array}{c}0.0000 \\
{[0.20]}\end{array}$ & & $\begin{array}{c}0.0000 \\
{[0.39]}\end{array}$ & $\begin{array}{l}-0.0001 \\
{[-0.66]}\end{array}$ & \\
\hline Availability of a possible acquirer (\%) & $\begin{array}{c}-0.0001^{* *} \\
{[-2.31]}\end{array}$ & $\begin{array}{c}-0.0003 * * * \\
{[-4.73]}\end{array}$ & & $\begin{array}{c}-0.0000 \\
{[-1.49]}\end{array}$ & $\begin{array}{c}-0.0002 * * * \\
{[-3.19]}\end{array}$ & & $\begin{array}{c}-0.0645^{* *} \\
{[-2.91]}\end{array}$ & $\begin{array}{c}-0.0000 \\
{[-0.58]}\end{array}$ & \\
\hline$\Delta$ Total assets (ln) & $\begin{array}{c}-0.0004 * \\
{[-1.67]}\end{array}$ & $\begin{array}{c}-0.0015 * * * \\
{[-4.49]}\end{array}$ & $\begin{array}{c}0.0258 * * \\
{[2.41]}\end{array}$ & $\begin{array}{c}-0.0007 * * * \\
{[-2.17]}\end{array}$ & $\begin{array}{c}-0.0010^{* *} \\
{[-2.19]}\end{array}$ & $\begin{array}{c}0.0153 \\
{[1.03]}\end{array}$ & $\begin{array}{c}-0.0004 * \\
{[-1.78]}\end{array}$ & $\begin{array}{c}-0.0003 * * \\
{[-2.13]}\end{array}$ & $\begin{array}{c}0.0361 * * \\
{[2.47]}\end{array}$ \\
\hline$\Delta$ Return on equity $(\%)$ & $\begin{array}{c}-0.0009 * * \\
{[-2.54]}\end{array}$ & $\begin{array}{c}-0.0002 \\
{[-0.59]}\end{array}$ & $\begin{array}{c}-0.1454 * * \\
{[-2.23]}\end{array}$ & $\begin{array}{c}-0.0005 \\
{[-0.98]}\end{array}$ & $\begin{array}{c}-0.0003 \\
{[-0.96]}\end{array}$ & $\begin{array}{c}-0.0196 \\
{[-1.20]}\end{array}$ & $\begin{array}{l}-0.0003 \\
{[-1.34]}\end{array}$ & $\begin{array}{r}-0.0002 \\
{[-0.73]}\end{array}$ & $\begin{array}{c}-0.0221 \\
{[-1.60]}\end{array}$ \\
\hline$\Delta$ Loan portfolio concentration $(\mathrm{HHI})(\%)$ & $\begin{array}{r}0.0007 \\
{[1.39]}\end{array}$ & $\begin{array}{l}0.0005 \\
{[1.00]}\end{array}$ & $\begin{array}{c}0.0145 \\
{[0.8387]}\end{array}$ & $\begin{array}{c}0.0008 \\
{[1.56]}\end{array}$ & $\begin{array}{c}0.0015^{* *} \\
{[2.37]}\end{array}$ & $\begin{array}{r}0.0168 \\
{[0.68]}\end{array}$ & $\begin{array}{l}-0.0002 \\
{[-0.52]}\end{array}$ & $\begin{array}{c}0.0003 \\
{[0.96]}\end{array}$ & $\begin{array}{c}0.0150 \\
{[0.52]}\end{array}$ \\
\hline$\Delta$ Fee income/Total income $(\%)$ & $\begin{array}{l}0.0001 \\
{[0.11]}\end{array}$ & $\begin{array}{c}0.0018^{*} \\
{[1.76]}\end{array}$ & $\begin{array}{c}0.0683^{*} \\
{[1.84]}\end{array}$ & $\begin{array}{c}0.0003 \\
{[0.27]}\end{array}$ & $\begin{array}{c}0.0023 * * \\
{[2.26]}\end{array}$ & $\begin{array}{c}0.1298 * * \\
{[2.52]}\end{array}$ & $\begin{array}{l}0.0005 \\
{[0.48]}\end{array}$ & $\begin{array}{l}0.0010 \\
{[1.22]}\end{array}$ & $\begin{array}{l}0.0203 \\
{[0.38]}\end{array}$ \\
\hline Tier1 capital/Total assets (\%) & $\begin{array}{c}-0.0045^{* * * *} \\
{[-4.58]}\end{array}$ & $\begin{array}{c}-0.0041 * * * \\
{[-4.20]}\end{array}$ & $\begin{array}{c}-0.0758^{* *} \\
{[-1.96]}\end{array}$ & $\begin{array}{c}-0.0038 * * * \\
{[-2.89]}\end{array}$ & $\begin{array}{c}-0.0019^{*} \\
{[-1.86]}\end{array}$ & $\begin{array}{c}-0.2744 * * * * \\
{[-2.87]}\end{array}$ & $\begin{array}{c}-0.0019^{* *} \\
{[-2.23]}\end{array}$ & $\begin{array}{l}0.0002 \\
{[0.41]}\end{array}$ & $\begin{array}{l}-0.0481 \\
{[-1.05]}\end{array}$ \\
\hline Nonperforming loans/Total loans (\%) & $\begin{array}{c}0.0072 * * * \\
{[9.81]}\end{array}$ & $\begin{array}{c}0.0116^{* * *} * \\
{[11.21]}\end{array}$ & $\begin{array}{c}0.0660 \\
{[1.27]}\end{array}$ & $\begin{array}{c}0.0049 * * * \\
{[5.70]}\end{array}$ & $\begin{array}{c}0.0060 * * * \\
{[5.03]}\end{array}$ & $\begin{array}{c}0.0784 \\
{[1.09]}\end{array}$ & $\begin{array}{c}0.0038^{* * *} \\
{[3.04]}\end{array}$ & $\begin{array}{c}0.0008 \\
{[1.40]}\end{array}$ & $\begin{array}{l}0.0231 \\
{[0.45]}\end{array}$ \\
\hline Local output growth (\%) & $\begin{array}{l}-0.000 \\
{[-0.21]}\end{array}$ & $\begin{array}{l}0.0001 \\
{[0.33]}\end{array}$ & $\begin{array}{r}-0.0027 \\
{[-0.26]}\end{array}$ & $\begin{array}{r}-0.0005 \\
{[-0.98]}\end{array}$ & $\begin{array}{c}-0.0000 \\
{[-0.22]}\end{array}$ & $\begin{array}{c}-0.0035 \\
{[-0.21]}\end{array}$ & $\begin{array}{c}-0.0003 \\
{[-0.87]}\end{array}$ & $\begin{array}{c}0.0005^{* * *} * \\
{[2.58]}\end{array}$ & $\begin{array}{l}0.0001 \\
{[0.00]}\end{array}$ \\
\hline Distance to nearest metropolitan area $(\mathrm{km}, \mathrm{ln})$ & $\begin{array}{l}-0.0026 \\
{[-1.59]}\end{array}$ & $\begin{array}{c}-0.0036^{*} \\
{[-1.82]}\end{array}$ & $\begin{array}{c}-0.0828 * * \\
{[-2.39]}\end{array}$ & $\begin{array}{c}-0.0018 \\
{[-1.15]}\end{array}$ & $\begin{array}{l}-0.0027 \\
{[-1.52]}\end{array}$ & $\begin{array}{c}-0.1531 * * \\
{[-2.35]}\end{array}$ & $\begin{array}{c}-0.0008 \\
{[-0.53]}\end{array}$ & $\begin{array}{c}-0.0004 \\
{[-0.46]}\end{array}$ & $\begin{array}{c}-0.0237 \\
{[-0.63]}\end{array}$ \\
\hline Banking pillar, year, and state dummies & Yes & Yes & Yes & Yes & Yes & Yes & Yes & Yes & Yes \\
\hline Observations & 17,342 & 17,342 & 17,342 & 8,675 & 8,675 & 8,675 & 8,667 & 8,667 & 8,667 \\
\hline Number of banks & 2,501 & 2,501 & 2,501 & 1,369 & 1,369 & 1,369 & 1,132 & 1,132 & 1,132 \\
\hline Hansen J statistic & & & 1.98 & & & 1.99 & & & 0.51 \\
\hline p-value of Hansen & & & 0.15 & & & 0.16 & & & 0.47 \\
\hline AP multivariate F-Test (Regulatory interventions) & $16.45 * * *$ & & & $8.68^{* * * *}$ & & & $6.20 * * *$ & & \\
\hline First stage F-Test (Regulatory interventions) & $11.51 * * *$ & & & $5.82 * * *$ & & & $5.10 * * *$ & & \\
\hline AP multivariate F-Test (Capital support) & & $14.27 * * *$ & & & $11.75^{* * *}$ & & & $5.55 * * *$ & \\
\hline First stage F-Test (Capital support) & & $9.83 * * *$ & & & $8.41 * * *$ & & & $4.06 * * *$ & \\
\hline
\end{tabular}


Table III: LC components and sample split by equity ratio

This table presents second-stage IV regressions to examine how regulatory interventions and capital support affect the main components of liquidity creation (asset-side, liability-side, and off-balance sheet liquidity creation). Panel A uses the full sample. Panel B splits the sample at the median equity ratio. The instruments are: the state vote share of pro-business parties (\%); the distance between the bank and its bankers association's provider of insurance $(\mathrm{km}, \mathrm{ln})$; and the availability of a possible acquirer (\%). Every regression includes a constant term, all the control variables shown in Table II, and banking pillar, year, and state dummies (not shown for brevity). The regressions are run in changes (exceptions are noted in Table II). The potentially endogenous explanatory variables and control variables are lagged by one year. Robust z-statistics are in brackets. Standard errors are clustered at the bank level. *** $\mathrm{p}<0.01, * * \mathrm{p}<0.05, * \mathrm{p}<0.1$

\begin{tabular}{|c|c|c|c|c|c|c|}
\hline \multicolumn{7}{|l|}{ Panel A: Full sample } \\
\hline Dependent variable & \multicolumn{2}{|c|}{$\Delta$ (LC asset side/Total assets) } & \multicolumn{2}{|c|}{$\Delta$ (LC liability side/Total assets) } & \multicolumn{2}{|c|}{$\Delta$ (LC off-balance sheet/Total assets) } \\
\hline Regulatory interventions & \multicolumn{2}{|c|}{$\begin{array}{l}1.7211 \\
{[0.40]}\end{array}$} & \multicolumn{2}{|c|}{$\begin{array}{c}-5.4444 * * \\
{[-2.19]}\end{array}$} & \multicolumn{2}{|c|}{$-4.4939 * * *$} \\
\hline Capital support & \multicolumn{2}{|c|}{$-10.5872 * * *$} & & $8.1194 * * *$ & \multicolumn{2}{|c|}{$\begin{array}{l}0.8018 \\
{[0.73]}\end{array}$} \\
\hline Control variables from Table II & \multicolumn{2}{|c|}{$[-2.79]$} & \multicolumn{2}{|c|}{ Yes } & \multicolumn{2}{|c|}{ Yes } \\
\hline Banking pillar, year, and state dummies & \multicolumn{2}{|c|}{ Yes } & \multicolumn{2}{|c|}{ Yes } & \multicolumn{2}{|c|}{ Yes } \\
\hline Observations & \multirow{2}{*}{\multicolumn{2}{|c|}{17,342}} & \multicolumn{2}{|c|}{17,342} & \multirow{2}{*}{\multicolumn{2}{|c|}{17,342}} \\
\hline Number of banks & \multirow{2}{*}{\multicolumn{2}{|c|}{2,501}} & \multicolumn{2}{|c|}{2,501} & & 2,501 \\
\hline Hansen J statistic & & & \multirow{2}{*}{\multicolumn{2}{|c|}{$\begin{array}{l}0.00 \\
0.95\end{array}$}} & \multicolumn{2}{|c|}{2.35} \\
\hline p-value of Hansen & \multicolumn{2}{|c|}{$\begin{array}{l}1.41 \\
0.22\end{array}$} & & & \multicolumn{2}{|c|}{0.12} \\
\hline AP multivariate F-Test (Regulatory interventions) & \multicolumn{2}{|c|}{$11.29 * * *$} & \multicolumn{2}{|c|}{$11.29 * * *$} & & \\
\hline First stage F-Test (Regulatory interventions) & & & & & & \\
\hline AP multivariate F-Test (Capital support) & & & & & & \\
\hline First stage F-Test (Capital support) & & & & & & \\
\hline Panel B: Sample split by equity ratio & & & & & & \\
\hline Dependent variable & $\Delta$ (LC asset & tal assets) & $\Delta($ LC liab & de/Total assets) & $\Delta(\mathrm{LC}$ & eet/Total assets) \\
\hline & $\begin{array}{c}\text { Equity ratio } \\
\leq \mathrm{p} 50\end{array}$ & $\begin{array}{c}\text { Equity ratio } \\
>\text { p50 }\end{array}$ & $\begin{array}{c}\text { Equity ratio } \\
\leq \mathrm{p} 50\end{array}$ & $\begin{array}{l}\text { Equity ratio } \\
>\text { p50 }\end{array}$ & $\begin{array}{c}\text { Equity ratio } \\
\leq \mathrm{p} 50\end{array}$ & $\begin{array}{l}\text { Equity ratio } \\
>\text { p50 }\end{array}$ \\
\hline Regulatory interventions & 0.0090 & 1.5870 & $-7.1464 * *$ & -2.8153 & $-3.7896^{* * *}$ & $-4.6243 * * *$ \\
\hline & [0.00] & [0.24] & {$[-2.07]$} & {$[-0.92]$} & {$[-2.47]$} & {$[-2.61]$} \\
\hline Capital support & $\begin{array}{c}-6.2411 * * \\
{[-2.11]}\end{array}$ & $\begin{array}{c}-9.1566 \\
{[-1.13]}\end{array}$ & $\begin{array}{l}5.0410 * * \\
{[2.19]}\end{array}$ & $\begin{array}{c}9.0893^{*} \\
{[1.80]}\end{array}$ & $\begin{array}{r}0.8633 \\
{[0.84]}\end{array}$ & $\begin{array}{l}1.6985 \\
{[0.75]}\end{array}$ \\
\hline Control variables from Table II & Yes & Yes & Yes & Yes & Yes & Yes \\
\hline Banking pillar, year, and state dummies & Yes & Yes & Yes & Yes & Yes & Yes \\
\hline Observations & 8,675 & 8,667 & 8,675 & 8,667 & 8,675 & 8,667 \\
\hline Number of banks & 1,369 & 1,132 & 1,369 & 1,132 & 1,369 & 1,132 \\
\hline Hansen $\mathbf{J}$ statistic & 1.72 & 5.92 & 0.85 & 7.45 & 4.07 & 0.09 \\
\hline p-value of Hansen & 0.18 & 0.01 & 0.35 & 0.00 & 0.04 & 0.75 \\
\hline AP multivariate F-Test (Regulatory interventions) & $5.82 * * *$ & $6.20^{* * *}$ & $5.82 * * *$ & $6.20 * * *$ & $5.82 * * *$ & $6.20 * * *$ \\
\hline First stage F-Test (Regulatory interventions) & $8.68^{* * * *}$ & $5.10^{* * * *}$ & $8.68^{* * *}$ & $5.10 * * *$ & 8.68 *** & $5.10^{* * * *}$ \\
\hline AP multivariate F-Test (Capital support) & $11.75^{* * *}$ & $5.55^{* * *}$ & $11.75 * * *$ & $5.55^{* * * *}$ & $11.75^{* * *} *$ & $5.55 * * *$ \\
\hline First stage F-Test (Capital support) & $8.41 * * *$ & $4.06^{* * *}$ & $8.41 * * *$ & $4.06 * * *$ & $8.41 * * *$ & $4.06 * * *$ \\
\hline
\end{tabular}




\section{Table IV Extensions: Lending and risk taking}

This table presents second-stage IV regressions to show how regulatory interventions and capital support affect lending and risk taking. We examine changes in total loans and two key lending categories, corporate loans and retail loans (all scaled by total assets). Changes in risk taking are measured by changes in the Z-Score (ln) and changes in the ratio of risk weighted assets to total assets. The instruments are: the state vote share of pro-business parties (\%); the distance between the bank and its bankers association's provider of insurance (kilometers, ln); and the availability of a possible acquirer (\%). Every regression includes a constant term, all the control variables shown in Table II, and banking pillar, year, and state dummies (not shown for brevity). The regressions are run in changes (exceptions are noted in Table II). The potentially endogenous explanatory variables and control variables are lagged by one year. Robust z-statistics are in brackets. Standard errors are clustered at the bank level. *** $\mathrm{p}<0.01, * * \mathrm{p}<0.05, * \mathrm{p}<0.1$.

\begin{tabular}{|c|c|c|c|c|c|}
\hline \multirow[b]{2}{*}{ Dependent variable } & \multicolumn{3}{|c|}{ Change in lending } & \multicolumn{2}{|c|}{ Change in risk taking } \\
\hline & $\Delta$ (Total loans/Total assets) & $\begin{array}{c}\Delta \text { (Corporate loans/Total } \\
\text { assets) }\end{array}$ & $\begin{array}{c}\Delta \text { (Retail loans/Total } \\
\text { assets) }\end{array}$ & $\Delta$ Z-Score $(\ln )$ & $\Delta$ (RWA/Total assets) \\
\hline Regulatory interventions & $\begin{array}{c}-3.1662 \\
{[-0.75]}\end{array}$ & $\begin{array}{r}-1.7619 \\
{[-0.59]}\end{array}$ & $\begin{array}{r}-0.6785 \\
{[-0.29]}\end{array}$ & $\begin{array}{l}3.8324 * * * \\
{[2.71]}\end{array}$ & $\begin{array}{c}-10.5363^{* *} \\
{[-2.07]}\end{array}$ \\
\hline Capital support & $\begin{array}{l}-15.2090 * * * \\
{[-3.2]}\end{array}$ & $\begin{array}{c}-11.0787 * * * \\
{[-3.47]}\end{array}$ & $\begin{array}{c}-4.7079 * \\
{[-1.91]}\end{array}$ & $\begin{array}{c}2.6981 * * \\
{[2.09]}\end{array}$ & $\begin{array}{c}-14.9831 * * * \\
{[-2.98]}\end{array}$ \\
\hline $\begin{array}{l}\text { Control variables from Table II } \\
\text { Banking pillar, vear, and state dummies }\end{array}$ & $\begin{array}{l}\text { Yes } \\
\text { Yes }\end{array}$ & $\begin{array}{l}\text { Yes } \\
\text { Yes }\end{array}$ & $\begin{array}{l}\text { Yes } \\
\text { Yes }\end{array}$ & $\begin{array}{l}\text { Yes } \\
\text { Yes }\end{array}$ & $\begin{array}{l}\text { Yes } \\
\text { Yes }\end{array}$ \\
\hline Observations & 17,342 & 17,342 & 17,342 & 17,342 & 17,342 \\
\hline Number of banks & 2,501 & 2,501 & 2,501 & 2,501 & 2,501 \\
\hline Hansen J statistic & 2.37 & 2.60 & 0.65 & 0.00 & 1.21 \\
\hline p-value of Hansen & 0.12 & 0.10 & 0.41 & 0.94 & 0.27 \\
\hline AP multivariate F-Test (Regulator interventions) & $16.45 * * *$ & $16.45 * * *$ & $16.45 * * *$ & $16.45^{* * * *}$ & $16.45 * * *$ \\
\hline First stage F-Test (Regulatory interventions) & $11.51 * * *$ & $11.51 * * *$ & $11.51 * * *$ & $11.51 * * *$ & $11.51 * * *$ \\
\hline AP multivariate F-Test (Capital support) & $14.27 * * *$ & $14.27 * * *$ & $14.27 * * *$ & $14.27 * * *$ & $14.27 * * *$ \\
\hline First stage F-Test (Capital support) & $9.83 * * *$ & $9.83 * * *$ & $9.83 * * *$ & $9.83 * * *$ & $9.83 * * *$ \\
\hline
\end{tabular}




\section{Table V: Types of regulatory interventions}

This table presents second-stage IV regressions to show how different types of regulatory interventions as well as capital support affect liquidity creation and its components (asset-side, liability-side, and off-balance sheet liquidity creation). Panel A splits regulatory interventions by severity (into those that are moderate and those that are severe), and Panel B splits them by orientation (into those that directly affect business activities and those that directly affect management). As instruments we use: the state vote share of pro-business parties (\%); the distance between the bank and its bankers association's provider of insurance ( $\mathrm{km}, \mathrm{ln})$; and the availability of a possible acquirer (\%). Every regression includes a constant term, all the control variables shown in Table II, and banking pillar, year, and state dummies (not shown for brevity). The regressions are run in changes (exceptions are noted in Table II). The potentially endogenous explanatory variables and all control variables are lagged by one year. Robust z-statistics are in brackets. Standard errors are clustered at the bank level. $* * * \mathrm{p}<0.01, * * \mathrm{p}<0.05, * \mathrm{p}<0.1$

\begin{tabular}{|c|c|c|c|c|c|c|c|c|}
\hline \multirow{2}{*}{$\begin{array}{l}\text { Panel A: Regulatory interventions by severity } \\
\text { Dependent variable }\end{array}$} & \multicolumn{2}{|c|}{ Liquidity creation } & \multicolumn{6}{|c|}{ Components of liquidity creation } \\
\hline & $\begin{array}{c}\Delta \text { (LC } \\
\text { /Total assets) }\end{array}$ & $\begin{array}{c}\Delta \text { (LC } \\
\text { /Total assets) }\end{array}$ & $\begin{array}{l}\Delta \text { (LC asset side } \\
\text { /Total assets) }\end{array}$ & $\begin{array}{l}\Delta \text { (LC asset side } \\
\text { /Total assets) }\end{array}$ & $\begin{array}{c}\Delta \text { (LC liability side } \\
\text { /Total assets) }\end{array}$ & $\begin{array}{l}\Delta \text { (LC liability side } \\
\text { /Total assets) }\end{array}$ & $\begin{array}{l}\Delta \text { (LC off-balance } \\
\text { sheet/Total assets) }\end{array}$ & $\begin{array}{l}\Delta \text { (LC off-balance } \\
\text { sheet/Total assets) }\end{array}$ \\
\hline Regulatory interventions (moderate) & $\begin{array}{c}-11.0956^{* *} \\
{[-2.01]}\end{array}$ & & $\begin{array}{c}2.2427 \\
{[0.45]}\end{array}$ & & $\begin{array}{c}-6.3070^{* *} \\
{[-2.17]}\end{array}$ & & $\begin{array}{c}-5.1133 * * * \\
{[-3.83]}\end{array}$ & \\
\hline Regulatory interventions (severe) & & $\begin{array}{c}-27.8719 * * \\
{[-1.99]}\end{array}$ & & $\begin{array}{l}1.2594 \\
{[0.11]}\end{array}$ & & $\begin{array}{c}-13.5496^{* *} \\
{[-2.03]}\end{array}$ & & $\begin{array}{c}-12.3100^{* * * *} \\
{[-2.91]}\end{array}$ \\
\hline Capital support & $\begin{array}{c}-3.9372 \\
{[-0.97]}\end{array}$ & $\begin{array}{r}-1.2811 \\
{[-0.25]}\end{array}$ & $\begin{array}{c}-10.4296^{* * * *} \\
{[-2.81]}\end{array}$ & $\begin{array}{c}-10.2883 * * * \\
{[-2.59]}\end{array}$ & $\begin{array}{c}7.5029 * * * \\
{[2.99]}\end{array}$ & $\begin{array}{c}8.6571^{* * * *} \\
{[3.12]}\end{array}$ & $\begin{array}{l}0.2791 \\
{[0.27]}\end{array}$ & $\begin{array}{l}1.4202 \\
{[0.91]}\end{array}$ \\
\hline Control variables from Table II & Yes & Yes & Yes & Yes & Yes & Yes & Yes & Yes \\
\hline Banking pillar, year, and state dummies & Yes & Yes & Yes & Yes & Yes & Yes & Yes & Yes \\
\hline Observations & 17,342 & 17,342 & 17,342 & 17,342 & 17,342 & 17,342 & 17,342 & 17,342 \\
\hline Number of banks & 2,501 & 2,501 & 2,501 & 2,501 & 2,501 & 2,501 & 2,501 & 2,501 \\
\hline Hansen J statistic & 2.37 & 0.49 & 1.41 & 1.74 & 0.01 & 0.10 & 3.22 & 0.27 \\
\hline p-value of Hansen & 0.12 & 0.48 & 0.23 & 0.18 & 0.89 & 0.75 & 0.07 & 0.60 \\
\hline AP multivariate F-Test (Regulatory interventions) & $18.07 * * *$ & $6.00 * * *$ & $18.07 * * *$ & $6.00 * * *$ & $18.07 * * *$ & $6.00 * * *$ & $18.07 * * *$ & $6.00^{* * * *}$ \\
\hline First stage F-Test (Regulatory interventions) & $12.24 * * *$ & $4.48^{* * * *}$ & $12.24 * * *$ & $4.48 * * *$ & $12.24 * * *$ & $4.48 * * *$ & $12.24 * * *$ & $4.48^{* * *}$ \\
\hline AP multivariate F-Test (Capital support) & $14.67 * * *$ & $13.65^{* * * *}$ & $14.67 * * *$ & $13.65^{* * * *}$ & $14.67 * * *$ & $13.65 * * *$ & $14.67 * * *$ & $13.65 * * *$ \\
\hline First stage F-Test (Capital support) & $9.83^{* * *}$ & $9.38 * * *$ & $9.83^{* * * *}$ & $9.38 * * *$ & $9.83 * * *$ & $9.38 * * *$ & $9.83 * * *$ & $9.38 * * *$ \\
\hline \multicolumn{3}{|c|}{ Panel B: Regulatory interventions by orientation $\quad$ Liquidity creation } & \multicolumn{6}{|c|}{ Components of liquidity creation } \\
\hline Dependent variable & $\begin{array}{c}\Delta \text { (LC } \\
\text { /Total assets) }\end{array}$ & $\begin{array}{c}\Delta \text { (LC } \\
/ \text { Total assets })\end{array}$ & $\begin{array}{l}\Delta \text { (LC asset side } \\
\text { /Total assets) }\end{array}$ & $\begin{array}{l}\Delta \text { (LC asset side } \\
\text { /Total assets) }\end{array}$ & $\begin{array}{c}\Delta \text { (LC liability side } \\
\text { /Total assets) }\end{array}$ & $\begin{array}{l}\Delta \text { (LC liability } \\
\text { side } \\
\text { /Total assets })\end{array}$ & $\begin{array}{l}\Delta \text { (LC off-balance } \\
\text { sheet } \\
\text { /Total assets })\end{array}$ & $\begin{array}{l}\Delta \text { (LC off-balance } \\
\text { sheet } \\
\text { /Total assets) }\end{array}$ \\
\hline Regulatory interventions (business activities) & $\begin{array}{c}-55.6638 \\
{[-1.48]}\end{array}$ & & $\begin{array}{l}6.9183 \\
{[0.29]}\end{array}$ & & $\begin{array}{c}-29.3691 \\
{[-1.47]}\end{array}$ & & $\begin{array}{c}-25.1227^{*} \\
{[-1.79]}\end{array}$ & \\
\hline Regulatory interventions (management) & & $\begin{array}{c}-10.3115^{* * *} \\
{[-2.07]}\end{array}$ & & $\begin{array}{l}1.7894 \\
{[0.39]}\end{array}$ & & $\begin{array}{c}-5.7068 * * \\
{[-2.25]}\end{array}$ & & $\begin{array}{c}-4.7159 * * * \\
{[-4.00]}\end{array}$ \\
\hline Capital support & $\begin{array}{l}4.7538 \\
{[0.54]}\end{array}$ & $\begin{array}{l}-4.2862 \\
{[-1.05]}\end{array}$ & $\begin{array}{c}-11.3802 * * \\
{[-2.05]}\end{array}$ & $\begin{array}{c}-10.3214 * * * \\
{[-2.79]}\end{array}$ & $\begin{array}{c}12.0205^{* *} \\
{[2.44]}\end{array}$ & $\begin{array}{c}7.2848 * * * \\
{[2.97]}\end{array}$ & $\begin{array}{l}4.1857 \\
{[1.28]}\end{array}$ & $\begin{array}{l}0.1136 \\
{[0.11]}\end{array}$ \\
\hline Control variables from Table II & Yes & Yes & Yes & Yes & Yes & Yes & Yes & Yes \\
\hline Banking pillar, year, and state dummies & Yes & Yes & Yes & Yes & Yes & Yes & Yes & Yes \\
\hline Observations & 17,342 & 17,342 & 17,342 & 17,342 & 17,342 & 17,342 & 17,342 & 17,342 \\
\hline Number of banks & 2,501 & 2,501 & 2,501 & 2,501 & 2,501 & 2,501 & 2,501 & 2,501 \\
\hline Hansen J statistic & 0.50 & 2.08 & 1.54 & 1.48 & 0.00 & 0.00 & 0.30 & 2.67 \\
\hline p-value of Hansen & 0.47 & 0.14 & 0.21 & 0.22 & 0.95 & 0.95 & 0.58 & 0.10 \\
\hline AP multivariate F-Test (Regulatory interventions) & 1.83 & $19.78^{* * * *}$ & 1.83 & $19.78^{* * * *}$ & 1.83 & $19.78^{* * *}$ & 1.83 & $19.78^{* * *}$ \\
\hline First stage F-Test (Regulatory interventions) & $2.42 *$ & $13.35^{* * *}$ & $2.42 *$ & $13.35^{* * * *}$ & $2.42 *$ & $13.35^{* * *}$ & $2.42 *$ & $13.35 * * *$ \\
\hline AP multivariate F-Test (Capital support) & $8.39 * * *$ & $14.73 * * *$ & $8.39 * * *$ & $14.73 * * *$ & $8.39 * * *$ & $14.73 * * *$ & $8.39 * * *$ & $14.73 * * *$ \\
\hline First stage F-Test (Capital support) & $9.83 * * *$ & $9.83 * * *$ & $9.83 * * *$ & $9.83 * * *$ & $9.83 * * *$ & $9.83 * * *$ & $9.83 * * *$ & $9.83^{* * * *}$ \\
\hline
\end{tabular}




\section{Table VI: Long-run effects}

This table presents the long-run effects of regulatory interventions and capital support on liquidity creation and its components (asset-side, liability-side, and off-balance sheet liquidity creation). Each column presents the second stage of a single IV regression: we do not include lags of multiple lengths of regulatory interventions and capital support in the same regression because of the dearth of available instruments. The individual columns present the coefficients for the $n$-th lag of these key variables, instrumented by the $n$-th lag of the state vote share of pro-business parties (\%), the $n$-th lag of the distance to the bankers association's provider of insurance (kilometers, In), and the $n$-th lag of the availability of a possible acquirer (\%), with $n=2,3,4$. Every regression includes a constant term, all the contro variables shown in Table II, and banking pillar, year, and state dummies (not shown for brevity). The regressions are run in changes (exceptions are noted in Table II). The potentially endogenous explanatory variables and all control variables are lagged by one year. Robust z-statistics are in brackets. Standard errors are clustered at the bank level. $* * * \mathrm{p}<0.01, * * \mathrm{p}<0.05,{ }^{*} \mathrm{p}<0.1$

\begin{tabular}{|c|c|c|c|c|c|c|c|c|c|c|c|c|}
\hline \multirow{2}{*}{$\begin{array}{l}\text { Dependent variable } \\
\text { Long-run effects }\end{array}$} & \multicolumn{3}{|c|}{$\Delta$ (LC/Total assets) } & \multicolumn{3}{|c|}{$\begin{array}{c}\Delta(\mathrm{LC} \text { asset side } \\
/ \text { Total assets })\end{array}$} & \multicolumn{3}{|c|}{$\begin{array}{c}\Delta \text { (LC liability side } \\
\text { /Total assets) }\end{array}$} & \multicolumn{3}{|c|}{$\begin{array}{c}\Delta \text { (LC off-balance sheet } \\
\text { /Total assets) }\end{array}$} \\
\hline & $\begin{array}{l}\text { after } 2 \\
\text { years }\end{array}$ & $\begin{array}{l}\text { after } 3 \\
\text { years }\end{array}$ & $\begin{array}{l}\text { after } 4 \\
\text { years }\end{array}$ & $\begin{array}{c}\text { after } 2 \\
\text { years }\end{array}$ & $\begin{array}{c}\text { after } 3 \\
\text { years }\end{array}$ & $\begin{array}{c}\text { after } 4 \\
\text { years }\end{array}$ & $\begin{array}{l}\text { after } 2 \\
\text { years }\end{array}$ & $\begin{array}{l}\text { after } 3 \\
\text { years }\end{array}$ & $\begin{array}{c}\text { after } 4 \\
\text { years }\end{array}$ & $\begin{array}{l}\text { after } 2 \\
\text { years }\end{array}$ & $\begin{array}{c}\text { after } 3 \\
\text { years }\end{array}$ & $\begin{array}{c}\text { after } 4 \\
\text { years }\end{array}$ \\
\hline Key variables (lag structure) & & & & & & & & & & & & \\
\hline Regulatory interventions (t-2) & $\begin{array}{l}-9.7816 \\
{[-0.98]}\end{array}$ & & & $\begin{array}{c}-16.5085 \\
{[-1.54]}\end{array}$ & & & $\begin{array}{l}4.9429 \\
{[0.97]}\end{array}$ & & & $\begin{array}{l}6.6121 \\
{[1.56]}\end{array}$ & & \\
\hline Capital support (t-2) & $\begin{array}{l}-9.9888 \\
{[-1.64]}\end{array}$ & & & $\begin{array}{c}-15.7277 \\
{[-1.25]}\end{array}$ & & & $\begin{array}{l}7.1765 \\
{[1.13]}\end{array}$ & & & $\begin{array}{r}-0.1031 \\
{[-0.06]}\end{array}$ & & \\
\hline Regulatory interventions (t-3) & & $\begin{array}{c}-3.8483 \\
{[-0.32]}\end{array}$ & & & $\begin{array}{c}-13.5773 \\
{[-1.55]}\end{array}$ & & & $\begin{array}{c}13.3948 \\
{[1.43]}\end{array}$ & & & $\begin{array}{l}9.3771 \\
{[1.38]}\end{array}$ & \\
\hline Capital support (t-3) & & $\begin{array}{c}-10.4478 \\
{[-1.56]}\end{array}$ & & & $\begin{array}{c}-20.9952 \\
{[-1.48]}\end{array}$ & & & $\begin{array}{l}5.5658 \\
{[1.37]}\end{array}$ & & & $\begin{array}{l}-0.8917 \\
{[-0.44]}\end{array}$ & \\
\hline Regulatory interventions (t-4) & & & $\begin{array}{c}30.3738 \\
{[1.51]}\end{array}$ & & & $\begin{array}{l}8.9470 \\
{[0.75]}\end{array}$ & & & $\begin{array}{c}10.0754 \\
{[1.20]}\end{array}$ & & & $\begin{array}{c}12.0827 \\
{[2.04]}\end{array}$ \\
\hline Capital support (t-4) & & & $\begin{array}{c}-3.7490 \\
{[-0.45]}\end{array}$ & & & $\begin{array}{c}-10.9096 \\
{[-1.10]}\end{array}$ & & & $\begin{array}{l}6.9015 \\
{[1.60]}\end{array}$ & & & $\begin{array}{c}-0.0458 \\
{[-0.01]}\end{array}$ \\
\hline Control variables from Table II & Yes & Yes & Yes & Yes & Yes & Yes & Yes & Yes & Yes & Yes & Yes & Yes \\
\hline Banking pillar, year, and state dummies & Yes & Yes & Yes & Yes & Yes & Yes & Yes & Yes & Yes & Yes & Yes & Yes \\
\hline Observations & 16,164 & 15,297 & 14,452 & 16,164 & 15,297 & 14,452 & 16,164 & 15,297 & 14,452 & 16,164 & 15,297 & 14,452 \\
\hline Number of banks & 2,472 & 2,451 & 2,405 & 2,472 & 2,451 & 2,405 & 2,472 & 2,451 & 2,405 & 2,472 & 2,451 & 2,405 \\
\hline Hansen J-statistic & 0.26 & 0.99 & 0.51 & 1.44 & 0.45 & 0.18 & 0.02 & 1.07 & 0.58 & 0.97 & 0.33 & 1.20 \\
\hline p-value Hansen & 0.60 & 0.31 & 0.47 & 0.22 & 0.50 & 0.66 & 0.88 & 0.29 & 0.44 & 0.32 & 0.56 & 0.27 \\
\hline AP multivariate F-Test (Regulatory interventions) & $6.67 * * *$ & $4.03 * *$ & $2.60^{*}$ & $6.67 * * *$ & $4.03 * *$ & $2.60^{*}$ & $6.67 * * *$ & $4.03 * *$ & $2.60^{*}$ & $6.67 * * *$ & $4.03 * *$ & $2.60^{*}$ \\
\hline First-stage F-Test (Regulatory interventions) & $14.98 * * *$ & $3.13 * *$ & $2.19 *$ & $14.98 * * *$ & $3.13 * *$ & $2.19 *$ & $14.98 * * *$ & $3.13 * *$ & $2.19 *$ & $14.98 * * *$ & $3.13 * *$ & $2.19 *$ \\
\hline AP multivariate F-Test (Capital support) & $10.76 * * *$ & $8.29 * * *$ & $6.62 * * *$ & $10.76^{* * * *}$ & $8.29 * * *$ & $6.62 * * *$ & $10.76 * * *$ & $8.29 * * *$ & $6.62 * * *$ & $10.76 * * *$ & $8.29 * * *$ & $6.62 * * *$ \\
\hline First-stage F-Test (Capital support) & $8.70 * * *$ & $6.92 * * *$ & $5.71 * *$ & $8.70 * * *$ & $6.92 * *$ & $5.71 * * *$ & $8.70^{* * * *}$ & $6.92 * * *$ & $5.71 * * *$ & $8.70^{* * * *}$ & $6.92 * * *$ & $5.71 * * *$ \\
\hline
\end{tabular}




\section{Appendix A. Bank liquidity creation}

We calculate a bank's $€$ amount of liquidity creation using a slight variation on Berger and Bouwman's (2009) three-step procedure, which is discussed below and illustrated in Table A.1.

In the first step, we classify bank assets, liabilities, and equity as liquid, semi-liquid, or illiquid based on the ease, cost, and time it takes for customers to withdraw liquid funds from the bank, and the ease, cost and time it takes for a bank to dispose of its obligations to meet these liquidity demands. We follow a similar principle for off-balance sheet items.

A small difference between our calculation of liquidity creation and the approach in Berger and Bouwman (2009) exists. They argue that all activities should be classified based on information on both product category and maturity. However, due to limitations of the U.S. data, Berger and Bouwman (2009) have to classify loans according to either category or maturity. The Bundesbank database, however, enables us to exploit information on both loan category and maturity when classifying these items. ${ }^{15}$

In the second step, we assign weights of either $+1 / 2,0$, or $-1 / 2$ to all bank activities that are classified in the previous step. The signs of the weights are consistent with liquidity creation theory, which states that liquidity is created when banks transform illiquid assets into liquid liabilities. Liquidity is destroyed when liquid assets are financed by illiquid liabilities or equity. Hence, we allocate positive weights to illiquid assets and liquid liabilities, while negative weights are applied to liquid assets and illiquid liabilities and equity. We use weights of $+1 / 2$ and $-1 / 2$ because liquidity creation is only half determined by the source or use of funds alone. We apply the intermediate weight of 0 to semi-liquid assets and liabilities, based on the assumption that

\footnotetext{
${ }^{15}$ Another difference is that Berger and Bouwman's (2009) preferred measure includes the gross fair values of offbalance sheet derivatives. Since only notional amounts are available in the Bundesbank database and since derivatives affect liquidity creation only marginally in the U.S., we assume that this holds in Germany as well and exclude derivatives from our measure of liquidity creation. This should not have a large effect since most banks operate with close to matched books.
} 
semi-liquid activities fall halfway between liquid and illiquid activities. In terms of off-balance sheet items, we follow Berger and Bouwman (2009) and apply positive weights to all illiquid guarantees.

In the third step, we combine the activities as classified and weighted in the first two steps to obtain two liquidity creation measures. These measures classify activities based on both maturity and category, and include off-balance sheet activities ('Mat Cat Fat'), as illustrated in Table A.1. 
Table A.1: Classification of bank activities and construction of the 'Mat Cat Fat' liquidity creation measure

Step 1: Classify all bank activities as liquid, semi-liquid, or illiquid based on product category ('Cat') and maturity ('Mat').

Step 2: Assign weights to the activities classified in Step 1.

\section{ASSETS:}

Illiquid assets $($ weight $=1 / 2)$

Loans to credit institutions $>1$ year $\quad$ Loans to credit institutions $\leq 1$ year

Loans to customers $>$ year

Loans to customers $\leq 1$ year

Liquid assets $($ weight $=-1 / 2)$

Premises

Cash and due from other institutions

Loans to credit institutions (due daily)

Exchange listed fixed income securities

Exchange listed equities and other non fixed income

securities

Intangible assets

subsidiaries

Non exchange listed fixed income securities

Exchange listed participation rights

Non exchange listed investme

Non exchange listed participation rights

Subordinated loans to customers

Subordinated loans to credit institutions

Other subordinated assets

Other real estate owned

\section{LIABILITIES PLUS EQUITY:}

Liquid liabilities $($ weight $=1 / 2)$

Liabilities to credit institutions (overnight funds)

Semi-liquid liabilities (weight $=0$ )

Ihiquid liabilities $($ weight $=-1 / 2)$

Other liabilities to customers (transactions deposits)

Savings deposits

Liabilities to credit institutions $>1$ year

Time deposits

Liabilities to credit institutions $\leq 1$ year

Other tradable liabilities $>1$ yea

Other tradable liabilities $\leq 1$ year

Bank's liability on bankers acceptances

Subordinated debt

Equity

\section{OFF-BALANCE SHEET ACTIVITIES:}

Illiquid guarantees (weight $=1 / 2$ )

Lines of credit

Guarantees

Standby letters of credit

All other off-balance sheet liabilities

Step 3: Combine bank activities as classified in Step 1 and as weighted in Step 2 to construct our liquidity creation measure (include off-balance sheet activities: 'Fat').

\section{Mat Cat Fat =}

$+1 / 2^{*}$ illiquid assets $+1 / 2^{*}$ liquid assets $+1 / 2^{*}$ illiquid guarantees 


\section{Appendix B. Geographic decomposition of banking markets}

This appendix shows the geographic segmentation of banking markets in Germany. It illustrates state borders using the federal state ("Bundesland") Bavaria as an example (Figure B.1), administrative district borders in Bavaria ("Regierungsbezirke", Figure B.2), and county borders in Upper Bavaria ("Landkreise”, Figure B.3). Counties are nested within administrative districts.

Figure B.1: Germany and the federal state ("Bundesland") Bavaria
Figure B.2: Administrative district borders in Bavaria ("Regierungsbezirke")
Figure B.3: County borders in Upper Bavaria ("Landkreise")

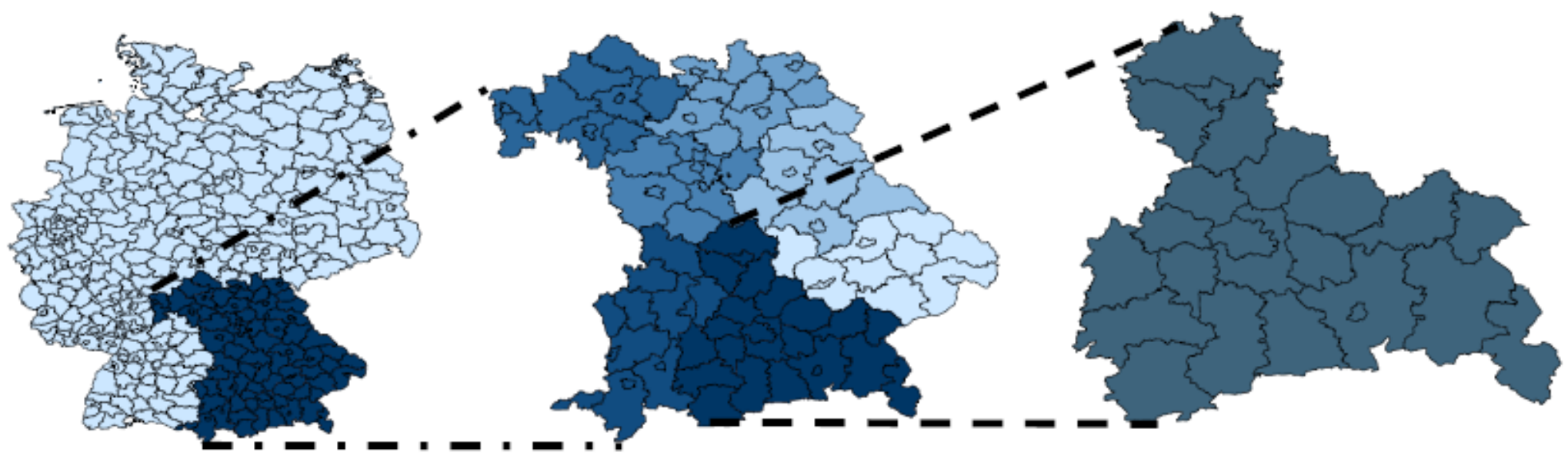


Appendix C. Distribution of regulatory interventions, capital support, and Z-Scores of sound banks (1999-2009)

This appendix shows the geographic distribution of regulatory interventions (Figure C.1) and capital support measures (Figure C.2). Figure C.3 shows the geographic distribution of sound banks'

Z-Scores ( $(\mathrm{ln})$. All data are averaged at the district level. Table C.1 shows the time distribution of regulatory interventions and capital support.

\section{Figure C.1}

Geographic distribution of regulatory interventions: Germany Share of regulatory interventions (district averages)

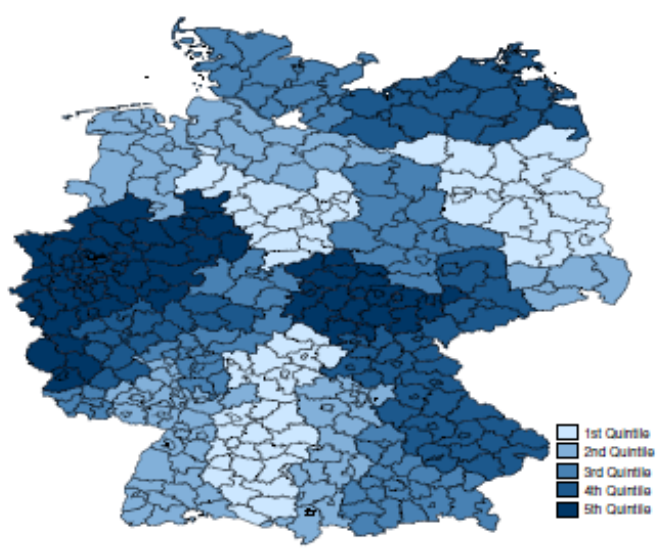

\section{Figure C.2}

Geographic distribution of capital support measures: Germany Share of capital support measures to Tier 1 capital (district averages)

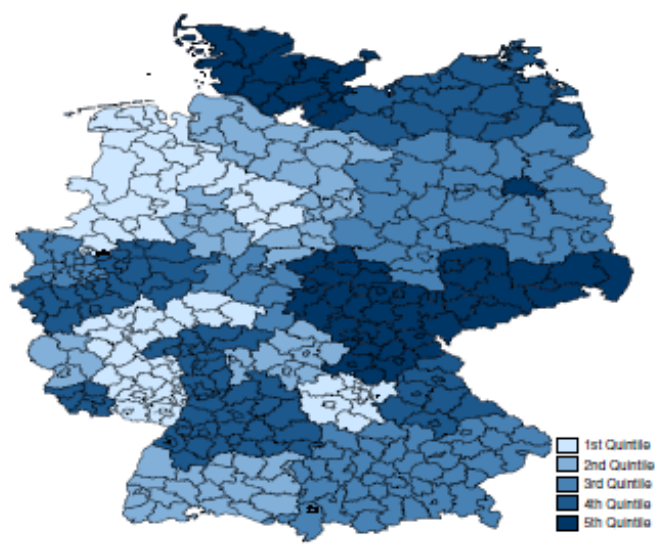

Figure C.3

Geographic distribution of Z-Score: Germany Share of Z-Score without regulatory interventions

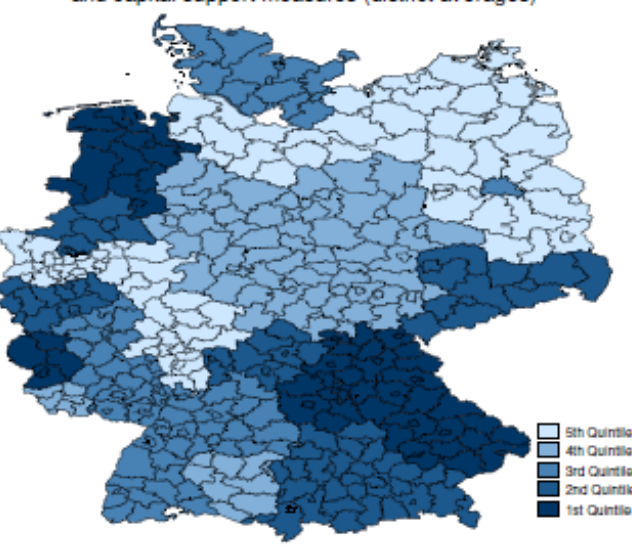

Table C.1: Time distribution of regulatory interventions and capital support (based on bank-year observations)

\begin{tabular}{|c|c|c|c|c|c|c|c|}
\hline \multirow[t]{2}{*}{ Year } & \multirow[t]{2}{*}{ Regulatory interventions } & \multirow[t]{2}{*}{ Capital support (dummy) } & \multicolumn{5}{|c|}{ Capital support (\% of Tier 1 capital) } \\
\hline & & & Mean & S.D. & $\mathrm{p} 25$ & p50 & p75 \\
\hline 1999 & 55 & 54 & 56.43 & 72.23 & 8.47 & 25.50 & 73.89 \\
\hline 2000 & 63 & 41 & 37.30 & 33.17 & 9.59 & 23.55 & 52.60 \\
\hline 2001 & 79 & 57 & 37.84 & 31.75 & 8.37 & 33.00 & 54.05 \\
\hline 2002 & 81 & 68 & 49.80 & 47.48 & 10.48 & 36.10 & 71.40 \\
\hline 2003 & 57 & 41 & 50.65 & 48.73 & 14.96 & 30.52 & 76.77 \\
\hline 2004 & 45 & 25 & 45.46 & 39.62 & 12.97 & 37.67 & 60.15 \\
\hline 2005 & 19 & 20 & 20.29 & 20.06 & 4.20 & 11.14 & 34.48 \\
\hline 2006 & 18 & 22 & 18.48 & 16.08 & 6.06 & 13.95 & 23.64 \\
\hline 2007 & 17 & 18 & 19.80 & 17.92 & 4.15 & 11.90 & 42.32 \\
\hline 2008 & 15 & 11 & 22.20 & 35.47 & 2.67 & 15.18 & 23.75 \\
\hline Total & 448 & 357 & 35.83 & 36.25 & 8.19 & 23.85 & 51.31 \\
\hline
\end{tabular}

